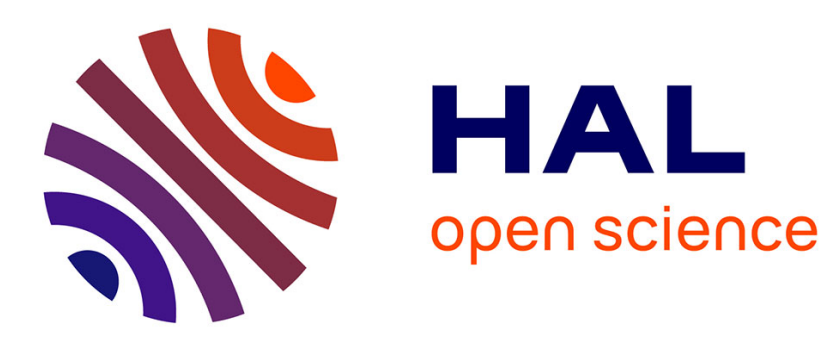

\title{
Monomeric and Dimeric Coordinatively Saturated and Substitutionally Inert Ru(II) Polypyridyl Complexes as Anticancer Drug Candidates
}

\author{
Anna Notaro, Gilles Gasser
}

\section{- To cite this version:}

Anna Notaro, Gilles Gasser. Monomeric and Dimeric Coordinatively Saturated and Substitutionally Inert Ru(II) Polypyridyl Complexes as Anticancer Drug Candidates. Chemical Society Reviews, 2017, 46 (23), pp.7317-7337. 10.1039/C7CS00356K . hal-01624345

\author{
HAL Id: hal-01624345 \\ https://hal.science/hal-01624345
}

Submitted on 26 Oct 2017

HAL is a multi-disciplinary open access archive for the deposit and dissemination of scientific research documents, whether they are published or not. The documents may come from teaching and research institutions in France or abroad, or from public or private research centers.
L'archive ouverte pluridisciplinaire HAL, est destinée au dépôt et à la diffusion de documents scientifiques de niveau recherche, publiés ou non, émanant des établissements d'enseignement et de recherche français ou étrangers, des laboratoires publics ou privés. 


\title{
Monomeric and Dimeric Coordinatively Saturated and Substitutionally Inert Ru(II) Polypyridyl Complexes as Anticancer Drug Candidates
}

\begin{abstract}
Anna Notaro, ${ }^{a}$ Gilles Gasser ${ }^{a, *}$
Due to the increasing impact of cancer on worldwide mortality, more and more attention is being devoted to the investigation of novel anticancer strategies. Among these, chemotherapy plays a key role in fighting cancer. This explains the increasing engagement of both pharmaceutical industry and academia towards the discovery of new chemotherapeutic agents. Over the recent years, metal-based drugs have attracted much attention due to their atypical physico-chemical properties compared to organic molecules. After the approval of cisplatin as a chemotherapeutic agent in 1978, several types of metal-based drugs have been explored. Among them, Ru-based anticancer drug candidates have become a central subject in this research field. However, most of the Ru-based compounds investigated over the last two decades express their cytotoxicity with a mechanism of action involving, among others, a ligand-exchange mechanism. In this Review, we give a complete overview of a specific class of antiproliferative ruthenium complexes, namely coordinatively saturated and substitutionally inert Ru(II) polypyridyl complexes. This implies that the cytotoxicity observed comes from the entire complex and not from a ligand-exchange. In this Review, we are presenting monomeric and dimeric $\mathrm{Ru}(\mathrm{II})$ polypyridyl complexes, which have been found to be toxic to cancer cells. More specifically, the monomeric $\mathrm{Ru}(\mathrm{II})$ polypyridyl complexes are analysed considering their direct interaction or not with DNA as cause of cell death, while dimeric Ru(II) polypyridyl complexes, are classified according to their biological targets. Very importantly, the cellular targets of these complexes are discussed in detail. Indeed, several targets were identified and different mechanisms of action

were

suggested.
\end{abstract}

\section{Introduction}

Cancer is a prominent cause of death worldwide. In high-income countries, it is already the main cause of mortality, a trend which is becoming more and more similar in low- and middle-income countries. $^{[1,2]}$ The latter increase is a consequence of the economic transition, which intensifies pollutants exposure due to the higher mechanisation in transports and labor. ${ }^{2}$ The adoption of cancerassociated lifestyle choices in these countries (e.g. smoking, physical inactivity, and "westernised" diets) is another cause of this rise. ${ }^{1}$ Furthermore, it has to be noted that other factors playing a key role in this increasing phenomena are population aging and growth, which are once again correlated with economic development. ${ }^{[2,3]}$ On the other hand, from data estimated by GLOBOCAN, a project from the World Health Organization to estimate cancer incidence, mortality and prevalence worldwide, ${ }^{[4,5]}$ it is interesting to note that even if the incidence rate for all cancers in developing countries is about half when compared with developed ones, the mortality rate is quite similar. This disparity between incidence and mortality can be related with the lack of prevention as much as with the shortage of appropriate therapeutic facilities and drug availability occurring in developing countries. ${ }^{1}$
To date, surgery is the most efficient treatment when used as a single form of cancer therapy since it can completely remove cancer from the organism. ${ }^{3}$ On the other hand, radiotherapy and chemotherapy are considered complementary techniques since they are able to kill only part of cancer cells in each treatment. ${ }^{3}$ However, surgery itself is only working for localised primary cancers. For all other cases such as metastatic cancers, a combination therapy is required. ${ }^{3}$ Due to these considerations, in recent years, more and more attention has been dedicated to the discovery of new chemotherapeutic agents.

Among the different agents investigated, metal-based drug candidates have been intensively studied since they present atypical physico-chemical properties compared to organic compounds. Among others, metal complexes offer a greater structural variety and the possibility of ligand exchange, which allows for the covalent interaction with biological molecular targets. ${ }^{[6-12]}$ Moreover, thanks to their precise three-dimensional configuration, they can recognise and interact with a defined molecular target, like, for example, the metal-based kinase inhibitors of Meggers. ${ }^{13}$ Since metals have access to different stable oxidation states, they can also react with the biological redox chemistry of cells. ${ }^{12}$ 
Cytotoxic chemotherapeutic agents damage proliferating cells. ${ }^{14}$ In some cases, as for cisplatin (1, Figure 1), this is achievable by inhibiting replication or by blocking biological pathways involved in DNA synthesis and cell cycle. ${ }^{7}$ Platinum-based drugs were investigated, for the first time, during the 1960s by Rosenberg and co-workers. ${ }^{[15-17]}$ These researchers discovered the ability of platinum complexes to inhibit cell divisions in bacteria. ${ }^{[15-17]}$ This activity gave the basis for the investigation of such complexes as a chemotherapeutic agents. ${ }^{18}$ The mechanism of action of cisplatin is believed to be linked to DNA damage, which involves the inhibition of replication, transcription or a combination of the two. ${ }^{19}$ Inter alia, cytotoxicity of cisplatin is due to the covalent crosslinks generated by its interaction with DNA. ${ }^{7}$ Its cytotoxicity is enhanced by the saturation of the cellular capacity to repair platinum adducts of DNA. Trans-adducts are repaired more easily than cis-adducts, explaining the 30 times difference in toxicity between cisplatin and transplatin. ${ }^{20}$ Although cisplatin is, to date, one of the most widely used and successful chemotherapeutic drugs, it exhibits severe side effects such as kidney damage, hearing loss, peripheral nerve damage, severe nausea and vomiting, and bone marrow suppression. ${ }^{19}$ These side effects as well as the phenomena of tumour resistance hampered cisplatin efficacy, limiting its clinical uses. In order to find a balance between the potential of cisplatin as a drug and its side effects, several different platinum-based compounds have been investigated like carboplatin and oxaliplatin (2 and 3, respectively in Figure 1), which achieved worldwide approval and use. ${ }^{[8,9]}$

Due to the discovery of the potential of cisplatin and its derivatives, an impressive amount of metal complexes have been explored as chemotherapeutic agents. ${ }^{[6,12,21-30]}$ Among these, ruthenium complexes play a key role since they present several advantages compared to other metal complexes. ${ }^{[31,32]}$ They have multiple stable oxidation states under physiological conditions and were found to possess unique properties during pre-clinical trials. ${ }^{[31,32]}$ They were indeed found to enter more selectively cancer cells than healthy cells, therefore reducing the toxic effects on healthy cells. ${ }^{32}$ The

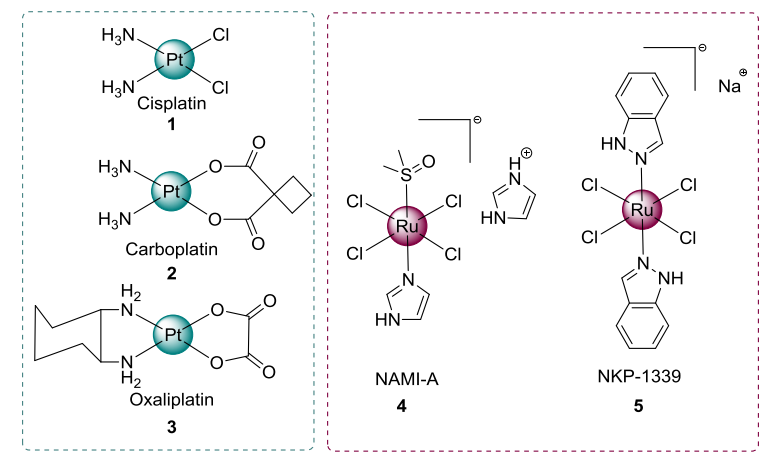

Fig. 1. Structures of metal-based drugs or drug candidates.

reason given for this observation was that they can mimic iron, which binds to transferrin proteins, whose receptors are largely overexpressed on malignant cells surface. This results in an increased uptake in cancer cells. ${ }^{33}$ However, this latter point is currently under

strong debate, as recently pointed out by Alessio in a nice review. $^{[33,34]}$ Importantly, compared to $\mathrm{Pt}(\mathrm{II})$ complexes, $\mathrm{Ru}$ complexes have a larger structural variety due to their octahedral geometry. ${ }^{[22,27]}$ In addition, $\mathrm{Ru}(\mathrm{III})$ and $\mathrm{Ru}(\mathrm{II})$ complexes usually have ligand exchange kinetics similar to those of $\mathrm{Pt}(\mathrm{II})$ complexes. ${ }^{31}$ They also own a well-developed synthetic chemistry. ${ }^{35}$ Nevertheless, structurally similar ruthenium compounds can behave differently in a biological setting and have therefore different biological targets. ${ }^{34}$ In fact, such compounds have an extensive diversity concerning their mechanisms of action, activities and toxicities. ${ }^{34}$ To date, two $\mathrm{Ru}(\mathrm{III})$ complexes, namely NAMI-A (4 in Figure 1) and NKP-1339 (5 in Figure 1) have entered into clinical trials. ${ }^{[36-39]}$ Chemistry speaking, their mechanisms of action are comparable to that of cisplatin with the involvement of ligand exchange but any other detailed explanation about this is beyond of the scope of this Review. We send the interested readers to excellent Reviews. ${ }^{[8,10,11,32,35,40-48,]}$ In this article, we are reviewing a specific type of ruthenium complexes, namely cytotoxic, coordinatively saturated and substitutionally inert $\mathrm{Ru}(\mathrm{II})$ polypyridyl complexes. Thus, since covalent binding is not possible for this type of metal complexes, their cytotoxicity must come from different mechanisms than those of cisplatin. Interestingly, as explained in detail below, they exert their cytotoxicity by inducing cell death through pathway activations, which often seem to be DNA independent. In this Review, we only present monomeric and dimeric Ru(II) polypyridyl complexes, which have been found to be toxic to cancer cells. More specifically, the monomeric $\mathrm{Ru}(\mathrm{II})$ polypyridyl complexes are 
analysed considering their direct interaction or not with DNA as cause of cell death. Dimeric Ru(II) polypyridyl complexes, on the other hand, are classified considering their biological targets. Decisively, only Ru(II) complexes fully characterised and whose biological activity was tested on cancer cell lines are reviewed. We also try to rationalise the antiproliferative activity of the complexes taking into account the experimental data (i.e. cellular uptake and cellular localization). However, we would like to highlight that the role of the counter-anions in the cytotoxicity of the $\mathrm{Ru}$ (II) complexes reported in this Review is not completely clear. It is known that the counter-anion can influence the solubility of a complex (i.e. KP1019 vs NKP1339). ${ }^{39}$ However, to the best of our knowledge, there has not been a study comparing the cytotoxicity of a $\mathrm{Ru}(\mathrm{II})$ polypyridyl complexes depending on its counter-anion. Very interestingly, a recent paper by Zhu presented a new method for delivering DNA 'light-switching' Ru(II) polypyridyl complexes into the nucleus of living cells. ${ }^{49}$ In this work, Zhu and co-workers demonstrated that the cell-impermeable Ru(II) polypyridyl cationic complexes might form novel lipophilic and relatively stable ion-pair complexes with three structurally unrelated hydrophobic weak acids (i.e. pentachlorophenol (PCP), carbonyl cyanide $p$ (trifluoromethoxy)phenylhydrazone (FCCP) and tolfenamic acid (TA)) leading to a remarkably enhanced nuclear uptake. ${ }^{49}$ From this work, scientists speculate that ion-pair formation might be a general, promising live-cell delivery method for cell-impermeable metal complexes and potentially bio-medically important. ${ }^{49}$ However, it is unclear if this has an impact on the cytotoxicity. In this Review, we will therefore make sure to mention every time the counter-anion employed in the biological studies. It is important to note that most of the studies reported in this Review are based on a continuation of previous works (i.e. researchers are trying to improve the cytotoxicity of a complex with the help of a structureactivity relationship study based on previous results which have shown that a complex was toxic to cancer cells). However, there are not, to the best of our knowledge, many examples of inert Ru(II) polypyridyl complexes, which have been rationally designed to aim for a specific target, like the Ru-based kinase inhibitors of Meggers, which are not discussed herein since this field was reviewed in detail. ${ }^{[50-53]}$ Recently, Ru(II) cyclometalated complexes have been also investigated as anticancer agents. ${ }^{[54-57]}$ However, this topic together with the $\mathrm{Ru}(\mathrm{II})$ polypyridyl complexes activated by light or the non-coordinatively saturated Ru(II) polypyridyl complexes are not reviewed here. We send the interested readers to an excellent, very recent Review of Zeng and co-workers. ${ }^{58}$ Over the years, many scientists focused their attention on reviewing the current state in medicinal chemistry of $\mathrm{Ru}$ complexes, ${ }^{[24,26,32,35,45,46,59-61]}$ in some cases considering only $\mathrm{Ru}(\mathrm{II})$ polypyridyl complexes and the possible applications. ${ }^{[62-64]}$ However, to the best of our knowledge, this is the first Review of the last 6 years focused only on the cytotoxicity of $\mathrm{Ru}(\mathrm{II})$ polypyridyl complexes.

\section{Historical overview of coordinatively saturated and substitutionally inert Ru(II) polypyridyl complexes}

Coordinatively saturated and substitutionally inert $\mathrm{Ru}(\mathrm{II})$ polypyridyl complexes such as $\left[\mathrm{Ru}(\text { phen })_{3}\right]\left(\mathrm{ClO}_{4}\right)_{2}(6)$ and $\left[\mathrm{Ru}(\mathrm{bpy})_{3}\right]\left(\mathrm{ClO}_{4}\right)_{2}(7)$ shown in Figure 2 were biologically investigated for the first time by the Australian scientist Dwyer and his co-workers in the 1950 s. ${ }^{[65-67]}$ The first study focused on the interaction of such complexes with enzymes as well as their bactericidal and bacteriostatic properties and toxicity to mice. Their first results showed that $\mathrm{Ru}(\mathrm{II})$ polypyridyl complexes exerted some bacteriostatic activity and were toxic for mice (toxic dose $>3 \mathrm{mg} / \mathrm{kg}$ ). The latter was associated with the inhibition of acetylcholinesterase, which is an enzyme mainly involved in neurotransmitter metabolism. ${ }^{65}$ Further studies of the acetylcholinesterase inhibition and in vivo evaluation of toxicity in mice suggested that this kind of neurotoxicity was charge-related. ${ }^{66}$ This observation was based on the inactivity showed by some neutral, analogue complexes such as $\mathrm{Co}\left(\mathrm{NH}_{3}\right)_{3}\left(\mathrm{NO}_{2}\right)_{3}$. The interaction accountable for the inhibitory activity, in fact, occurs between the positively charged complex and the negatively charged sites of the enzyme. ${ }^{66}$ The approval of penicillin in 1943 brought the pharmaceutical industry to mostly focus their attention on the development of new organic drugs. ${ }^{68}$ Therefore, historical reasons as much as the detection of severe side effects like neurotoxicity mentioned above, shadowed the biological investigation of Ru(II) polypyridyl complexes for more than fifty years. In the 1990s, Ru(II)

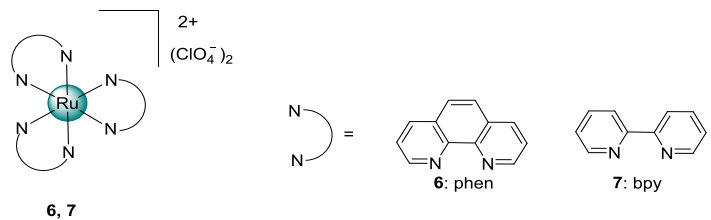

Fig. 2. Structures of $\left[\mathrm{Ru}(\text { phen })_{3}\right]\left(\mathrm{ClO}_{4}\right)_{2}(\mathbf{6}),\left[\mathrm{Ru}(\mathrm{bpy})_{3}\right]\left(\mathrm{ClO}_{4}\right)_{2}(\mathbf{7})$. 
polypyridyl complexes once again attracted much attention in the diagnostic field as DNA probes because of their interaction ability. ${ }^{[49,69-81]}$ From these studies, it was concluded that these complexes may interact with DNA through three different modes, namely electrostatic, non-intercalative ("surface" interaction) and intercalative binding mode with a quite consistent enantiomeric preference for the $\Delta$ form respective to the $\Lambda$ form. ${ }^{[22-88]}$ On the other hand, the potential anticancer activity of such compounds started to be reconsidered in 2000 when Liu and co-workers reported the in vitro cytotoxicity of some $\mathrm{Ru}(\mathrm{II})$ polypyridyl complexes. ${ }^{89}$ In this work, the toxicity of several $\mathrm{Ru}(\mathrm{II}) / \mathrm{Co}(\mathrm{III})$ polypyridyl complexes were tested against HL-60, BEL-7402, KB, and HeLa cells. The compounds, such as for $\left[\mathrm{Ru}(\mathrm{bpy})_{2}(\mathrm{dppz})\right]\left(\mathrm{BF}_{4}\right)_{2}(\mathbf{8}$, Figure 3 ), showed no cytotoxicity even though they were shown to be DNA intercalators and to strongly bind to DNA in some cases. ${ }^{74}$ On the other hand, it was pointed out that structurally similar compounds such as $\left[\mathrm{Ru}(\mathrm{bpy})_{2}(\mathrm{pztp})\right]\left(\mathrm{ClO}_{4}\right)_{2}$ and $\left[\mathrm{Ru}(\text { phen })_{2}(\right.$ pztp $\left.)\right]\left(\mathrm{ClO}_{4}\right)_{2}$ (9 and $\mathbf{1 0}$ in Figure 3 , respectively) express very different cytotoxicity against all the cancer cell lines tested $\left(I C_{50}=10 \mu \mathrm{M}\right.$ and $I C_{50} \geq 100 \mu \mathrm{M}$, respectively). ${ }^{89}$ These results gave the indication that the cytotoxicity of such complexes was strongly dependent on the metal, the ligand, and the shape of the complex. $^{89}$

\section{Mononuclear Ru(II) polypyridyl complexes}

In this part of the Review, mononuclear $\mathrm{Ru}(\mathrm{II})$ polypyridyl complexes are analysed considering their direct interaction(s) or not with DNA as cause of cell death (Sections 3.1 and 3.2, respectively). However, as can be seen below, mechanisms of action for $\mathrm{Ru}(\mathrm{II})$ polypyridyl complexes are often multiple or unclear, which have rendered this subdivision somewhat complicated. Caution is therefore to be taken

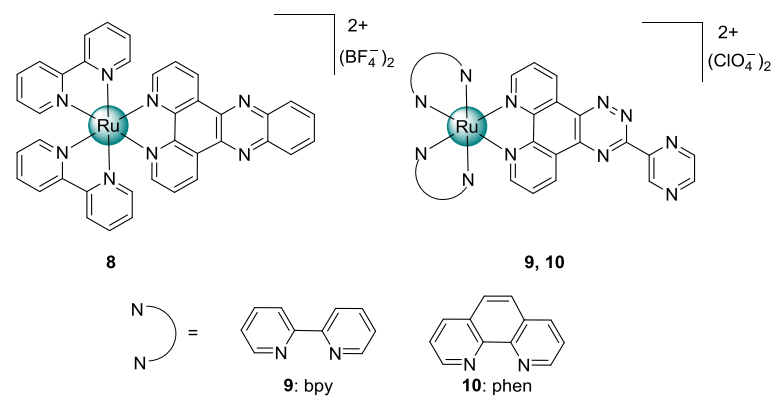

Fig. 3. Structures of $\left[\mathrm{Ru}(\mathrm{bpy})_{2}(\mathrm{dppz})\right]\left(\mathrm{BF}_{4}\right)_{2}(\mathbf{8}),\left[\mathrm{Ru}(\mathrm{bpy})_{2}(\mathrm{pztp})\right]\left(\mathrm{ClO}_{4}\right)_{2}$ (9), $\left[\mathrm{Ru}(\text { phen })_{2}(\right.$ pztp $\left.)\right]\left(\mathrm{ClO}_{4}\right)_{2}(\mathbf{1 0})$. about the complete appropriateness of this subdivision.

\subsection{Mechanisms of action involving direct interactions with DNA}

For many years, scientists have tried to correlate DNA-binding properties to the cytotoxicity expressed by $\mathrm{Ru}(\mathrm{II})$ polypyridyl complexes. ${ }^{[81,90-100]}$ In 2005 Hotze and co-workers were the first ones to evaluate the biological activity of some Ru(II) polypyridyl complexes since the report of Liu in 2000 (see above). ${ }^{89}$ Hotze et al. analysed the cytotoxicity of a series of $\mathrm{Ru}(\mathrm{II})$ polypyridyl complexes, i.e. $\operatorname{mer}-\left[\operatorname{Ru}(\text { azpy })_{3}\right]\left(\mathrm{PF}_{6}\right)_{2} \quad(\mathbf{1 1}), \quad \alpha-\left[\operatorname{Ru}(\operatorname{azpy})_{2}(\mathrm{bpy})\right]\left(\mathrm{PF}_{6}\right)_{2} \quad(\mathbf{1 2}), \quad \beta-$ $\left[\mathrm{Ru}(\text { azpy })_{2}(\mathrm{bpy})\right]\left(\mathrm{PF}_{6}\right)_{2}(\mathbf{1 3}),\left[\mathrm{Ru}(\mathrm{azpy})(\mathrm{bpy})_{2}\right]\left(\mathrm{PF}_{6}\right)_{2}$ (14) against A498, EVSTA-T, H226, IGROV, M19 MCF-7 and WIDR cell lines (Figure 4). ${ }^{90}$ In general, all the complexes showed moderate antiproliferative activity. In more detail, 11, $\mathbf{1 2}$ and $\mathbf{1 3}$ expressed greater cytotoxicity in $\mathrm{M} 19$ cells with $\mathrm{IC} \mathrm{C}_{50}=4.47 \mu \mathrm{M}, \mathrm{IC} \mathrm{C}_{50}=13.3 \mu \mathrm{M}$ and $\mathrm{IC} \mathrm{C}_{50}=19.5 \mu \mathrm{M}$, respectively for $\mathbf{1 1}, \mathbf{1 2}$ and $\mathbf{1 3}$ (Cisplatin $\mathrm{IC}_{50}=1.9 \mu \mathrm{M}$ ) while $\mathbf{1 4}$ was more active against $\mathrm{H} 226$ cells with $\mathrm{IC}_{50}=17.7 \mu \mathrm{M}$ and $\mathrm{IC}_{50}=10.9$ $\mu \mathrm{M}$ for $\mathbf{1 4}$ and cisplatin, respectively. Intercalative properties were suggested to be responsible for the cell death observed. ${ }^{90}$

In 2007, Ma and co-workers tested the cytotoxicity of $\left[R u\left(t B u_{2} \mathrm{bpy}_{2}(2-\mathrm{appt})\right]\left(\mathrm{PF}_{6}\right)_{2}\right.$ (15 in Figure 4), against KB- 3-1, KB-V1 , HepG-2 and HeLa cell lines. ${ }^{91}$ The complex was found to express moderate cytotoxicity in KB-3-1, HepG-2 and HeLa showing $\mathrm{IC}_{50}=$ $52.3 \pm 3.4 \mu \mathrm{M}, \quad I C_{50}=30.2 \pm 6 \mu \mathrm{M}$ and $\quad \mathrm{IC}_{50}=59.7 \pm 0.5 \mu \mathrm{M}$, respectively (cisplatin $\mathrm{IC}_{50}=22.1 \pm 3.6 \mu \mathrm{M}, \mathrm{IC}_{50}=10.5 \pm 0.5 \mu \mathrm{M}$ and $\mathrm{IC}_{50}=11.6 \pm 0.2$

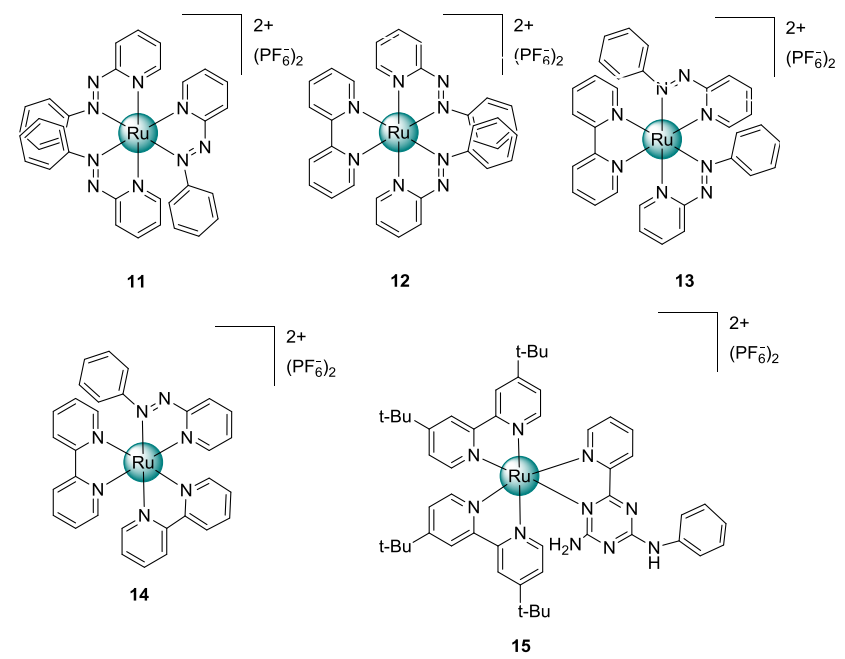

Fig. 4. Structures of mer-[Ru(azpy $\left.)_{3}\right]\left(\mathrm{PF}_{6}\right)_{2}(\mathbf{1 1}), \alpha-\left[\mathrm{Ru}(\mathrm{azpy})_{2}(\mathrm{bpy})\right]\left(\mathrm{PF}_{6}\right)_{2}(\mathbf{1 2})$, $\beta$-[Ru(azpy $)_{2}($ bpy $\left.)\right]\left(\mathrm{PF}_{6}\right)_{2} \quad(13), \quad\left[\mathrm{Ru}(\right.$ azpy $)\left(\right.$ (bpy $\left._{2}\right]\left(\mathrm{PF}_{6}\right)_{2} \quad(14) \quad$ and $\left[\mathrm{Ru}\left(t \mathrm{Bu}_{2} \mathrm{bpy}\right)_{2}(2-\mathrm{appt})\right]\left(\mathrm{PF}_{6}\right)_{2}(15)$ 
$\mu \mathrm{M}$, respectively). In this case, spectroscopic titrations and viscosity experiments indicated that complex $\mathbf{1 5}$ interacts with DNA via groove binding. In more detail, modelling studies suggested the minor groove as the preferential binding site. ${ }^{91}$

In 2010, from the investigation of the interaction between $[R u(2,9-$ dmp $\left.)_{2} \mathrm{PMIP}\right]\left(\mathrm{ClO}_{4}\right)_{2}(\mathbf{1 6}$, Figure 5) and calf thymus DNA (CT DNA) using several biophysical methods, Zhang and co-workers suggested that the antitumor activity observed for $\mathbf{1 6}$ against A549 cell line was related with its intercalation in CT DNA. ${ }^{92}$ One year later, Gill and co-workers examined the cytotoxicity of complexes $\left[\mathrm{Ru}(\mathrm{bpy})_{2}(\mathrm{tpphz})\right]\left(\mathrm{ClO}_{4}\right)_{2}$ and $\left[\mathrm{Ru}(\text { phen })_{2}(\mathrm{tpphz})\right]\left(\mathrm{ClO}_{4}\right)_{2}(\mathbf{1 7}$ and 18 shown in Figure 5, respectively). ${ }^{81}$ Both complexes bind DNA in vitro and act as DNA probes. ${ }^{[81,93]}$ In this work, these scientists demonstrated that these compounds were taken up by cells and displayed cytotoxicity towards MCF-7 and A2780 cells comparable with cisplatin. In both cases, complex $\mathbf{1 8}$ was found to be more cytotoxic than 17 and $A 2780$ cells to be more sensitive to the complexes compared with MCF-7. ${ }^{81}$ Inter alia, $I C_{50}=36 \pm 6 \mu \mathrm{M}, I C_{50}=$ $11 \pm 6 \mu \mathrm{M}$ and $\mathrm{IC}_{50}=12 \pm 2 \mu \mathrm{M}$ for 17,18 and cisplatin, respectively were determined against the A2780 cell line. Unlike cisplatin, both complexes retained their cytotoxicity against A2780-CP70 cisplatin resistant cell lines $\left(\mathrm{IC}_{50}=47 \pm 6 \mu \mathrm{M}, \mathrm{IC}_{50}=20 \pm 5 \mu \mathrm{M}\right.$ and $\mathrm{IC}_{50}=55 \pm 8$ $\mu \mathrm{M}$ for $\mathbf{1 7}, \mathbf{1 8}$, and cisplatin, respectively). ${ }^{81}$ Microscopy studies clearly showed internalisation of complex $\mathbf{1 8}$ but limited nuclear accumulation. These scientists speculated that such complexes could affect numerous cellular processes, such as DNA replication and translation. However, further studies are needed to clarify the exact mechanism of cytotoxicity. ${ }^{81}$

In 2012, [Ru(bpy $\left.)_{2}\left(\mathrm{H}_{2} \mathrm{IIP}\right)\right]\left(\mathrm{ClO}_{4}\right)_{2}$ (19 in Figure 6) was designed and synthesised by Liu and co-workers. ${ }^{85}$ In this case, the higher binding of an enantiomer to DNA/RNA was confirmed for both CT-DNA and

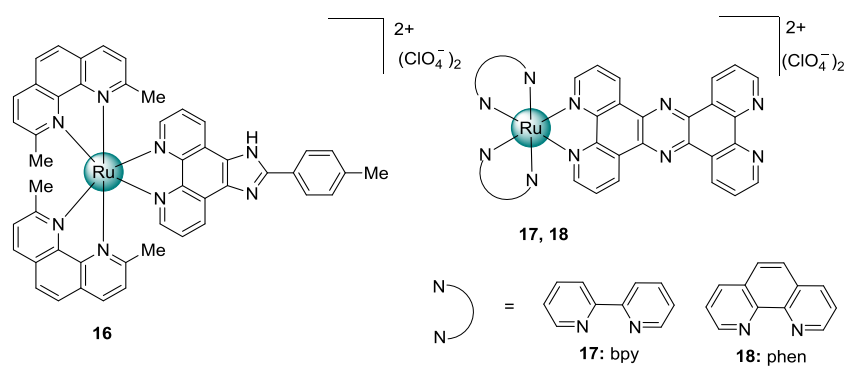

Fig. 5. Structures of $\left[\mathrm{Ru}(2,9-\mathrm{dmp})_{2} \mathrm{PMIP}\right]\left(\mathrm{ClO}_{4}\right)_{2}(\mathbf{1 6})$, $\left[\mathrm{Ru}(\mathrm{bpy})_{2}(\mathrm{tpphz})\right]\left(\mathrm{ClO}_{4}\right)_{2}$ (17) and $\left[\mathrm{Ru}(\text { phen })_{2}(\right.$ tpphz) $]\left(\mathrm{ClO}_{4}\right)_{2}$ (18). yeast tRNA, with 19 being a preferential binder for tRNA. Cytotoxicity tests were performed against HL-60 and HepG-2 cell lines using cisplatin as a control. ${ }^{85}$ In both cases 19 was found to be less cytotoxic than cisplatin with $\mathrm{IC}_{50}=18.36 \pm 1.35 \mu \mathrm{M}$ and $\mathrm{IC}_{50}=$ $5.85 \pm 0.44 \mu \mathrm{M}$ in $\mathrm{HL}-60$ and $\mathrm{IC}_{50}=20.45 \pm 1.53 \mu \mathrm{M}$ and $\mathrm{IC}_{50}=$ $11.18 \pm 0.84 \mu \mathrm{M}$ in HepG-2 for $\mathbf{1 9}$ and cisplatin, respectively. In this case, the scientists speculated that the cytotoxicity observed was related to other factors apart from DNA insertion, such as molecular shape of complex 19 and nature and chemical structure of the inserted ligand. ${ }^{85}$

Another kind of mechanism proposed for coordinatively saturated and substitutionally inert $\mathrm{Ru}(\mathrm{II})$ polypyridyl complexes is the inhibition of topoisomerases I and II, which are essential enzymes that control and modify the topological states of DNA. ${ }^{[01-103]}$ In 2012, Kou and co-workers suggested the inhibition of topoisomerases I and II for the cytotoxicity observed against HeLa, MCF-7, HepG2 and BEL-7402 tumour cell lines for two chiral Ru(II) anthraquinone complexes, $\Delta$ - and $\Lambda$ - $\left[\mathrm{Ru}(\mathrm{bpy})_{2}(\mathrm{ipad})\right]\left(\mathrm{ClO}_{4}\right)_{2}(\Delta / \Lambda-20$ in Figure 6). ${ }^{94}$ Both complexes demonstrated higher in vitro cytotoxicity against selected tumour cell lines than 5-fluorouracil, a widely used clinical antitumor drug, but relatively lower cytotoxicity than cisplatin. Similar findings were already discovered in 2011 for complexes $\mathbf{2 1}$ and $\mathbf{2 2}$ shown in Figure 6 by Du and co-workers. ${ }^{95}$ However, in the work of Kou and co-workers, the two enantiomers displayed small differences in antitumor activity against the tested cancer cell lines. This was suggested to be due to differences in DNA binding, hence leading to different topoisomerases inhibition. ${ }^{94}$ These scientists suggested that both complexes may block the DNA strand passage event of the enzyme and serve as catalytic inhibitors of topoisomerases. Experimental data suggested that complexes $\Delta$ and $\Lambda$-[Ru(bpy $\left.)_{2}(\mathrm{ipad})\right]\left(\mathrm{ClO}_{4}\right)_{2}$ may bind to the DNA by intercalative mode with $\Lambda$-enantiomer intercalating less deeply than $\Delta$ complex. ${ }^{94}$ Enantioselective DNA-binding is in accordance with previous data on similar complexes (i.e. $\Delta^{-}$and $\Lambda^{-}$ $\left[R u(b p y)_{2}(d p p z]^{2+}\right) \cdot{ }^{[84,88]}$ The enantioselectivity was found to be more consistent after the introduction of the antraquinone group. This can be attributed to the formation of specific hydrogen bond between the intercalated antraquinone group and DNA. ${ }^{94}$ The same mechanism was re-proposed two years later in 2014 by Wang and co-workers. The dual inhibition of topoisomerase I and II was suggested to be the base of 

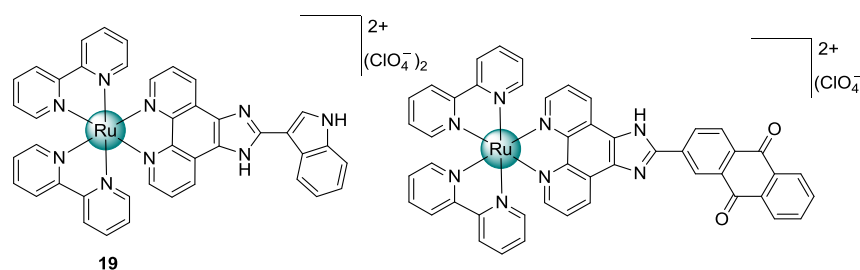

$\Delta / \Lambda-20$

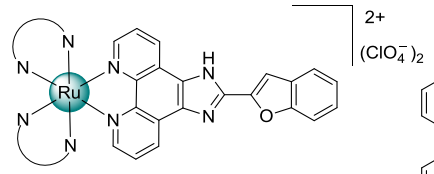

21,22
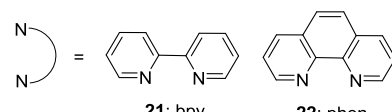

22: phen

Fig. 6. Structures of $\left[\mathrm{Ru}(\mathrm{bpy})_{2}\left(\mathrm{H}_{2} \mathrm{IIP}\right)\right]\left(\mathrm{ClO}_{4}\right)_{2} \quad$ (19), $\Delta^{-}$and $\Lambda^{-}$ $\left[\mathrm{Ru}(\mathrm{bpy})_{2}(\mathrm{ipad})\right]\left(\mathrm{ClO}_{4}\right)_{2} \quad(20), \quad\left[\mathrm{Ru}(\mathrm{bpy})_{2}(\mathrm{bfipH})\right]\left(\mathrm{ClO}_{4}\right)_{2} \quad$ (21) and $\left[\mathrm{Ru}(\text { phen })_{2}(\mathrm{bfipH})\right]\left(\mathrm{ClO}_{4}\right)_{2}(\mathbf{2 2}), \Lambda / \Delta-\left[\mathrm{Ru}(\mathrm{bpy})_{2}(\mathrm{pscl})\right]\left(\mathrm{ClO}_{4}\right)_{2} \quad$ (23) and $\Delta / \Lambda$ $\left[\mathrm{Ru}(\mathrm{bpy})_{2}(\mathrm{psbr})\right]\left(\mathrm{ClO}_{4}\right)_{2}(\mathbf{2 4})$.

the cytotoxicity exerted by two new enantiomeric pair of complexes such as $\Delta / \Lambda$ - $\left[\mathrm{Ru}(\mathrm{bpy})_{2}(\mathrm{pscl})\right]\left(\mathrm{ClO}_{4}\right)_{2}$ and $\Delta / \Lambda$ $\left[\mathrm{Ru}(\mathrm{bpy})_{2}(\mathrm{psbr})\right]\left(\mathrm{ClO}_{4}\right)_{2}((\Delta / \Lambda-23$ and $\Delta / \Lambda-24$, respectively in Figure 6). ${ }^{96}$ The cytotoxicity of these complexes was tested against HeLa, A549, HepG2 and BEL-7402 cell lines using NAMI-A and cisplatin as controls. The two enantiomers display a different cytotoxicity in agreement with the cellular uptake results obtained, with the $\Delta$ enantiomers being the most active. ${ }^{96}$ They displayed higher cytotoxicity when compared to NAMI-A but relatively lower compared to cisplatin. For example, in the case of HeLa cells (cell line against which the complexes where found to be the most active), $I C_{50}=41.8 \pm 2.3 \mu \mathrm{M}, I C_{50}=54.6 \pm 2.9 \mu \mathrm{M}, I C_{50}=515.7 \pm 17.4$ $\mu \mathrm{M}, \quad \mathrm{IC}_{50}=18.3 \pm 1.4 \mu \mathrm{M}$ for $\Delta-23, \Delta-24$, NAMI-A and cisplatin, respectively were determined. ${ }^{96}$ The $\mathrm{V}$ annexin stain method and flow cytometry analysis showed that complexes $\Delta-\mathbf{2 3}$ and $\Delta-\mathbf{2 4}$ induced apoptosis in HeLa cells. Moreover, topoisomerases inhibition studies and DNA relegation assays revealed that all four $\mathrm{Ru}$ (II) complexes acted as dual poisons of topoisomerase I and II and caused DNA damage. This could lead to cell cycle arrest and/or induction of apoptosis. $^{96}$

In 2013, Wang and co-workers proposed a new anticancer mechanism of action for Ru(II) polypyridyl complexes targeting DNA. $^{97}$ In this work, the in vitro cytotoxicity of $\left[\mathrm{Ru}(\text { bpy })_{2}(\mathrm{tip})\right]\left(\mathrm{PF}_{6}\right)_{2}$ (25, Figure 7) and $\left[\mathrm{Ru}(\text { phen })_{2}(\right.$ tip $\left.)\right]\left(\mathrm{PF}_{6}\right)_{2}(\mathbf{2 6}$, Figure 7$)$ against HeLa cells was investigated. Experimental data suggested the interaction of such complexes with G-quadruplex DNA, which is a secondary structure formed in specific guanine-rich sequences. ${ }^{104}$ Interestingly, DNA sequences that can form G-quadruplexes have been found in the upstream promoter of protoncogenes. ${ }^{105}$ Metal complexes are usually utilised as gene expression regulators promoting the formation and/or stabilising G-quadruplexes. ${ }^{[62,106]}$ Examples of Ru(II) polypyridyl complexes which preferentially target G-quadruplexes DNA over duplex DNA and are able to stabilise such structures are already present in the literature. ${ }^{[107-109]}$ Wang and coworkers demonstrated through in vitro experiments that both complexes (25 and $\mathbf{2 6}$ ) could induce and stabilise the formation of G-quadruplex in promotor of bcl-2 gene (B cell lymphoma gene 2). Cytotoxicity studies revealed antiproliferative activity on Hela cells, $\left(I C_{50}=22.10 \pm 1.01\right.$ and $18.56 \pm 0.67 \mu \mathrm{M}$, respectively for 25 and 26$)$. The highest cytotoxicity of complex $\mathbf{2 6}$ is consistent with its DNAbinding and ability to stabilise G-quadruplexes. ${ }^{97}$ In order to have more insights on the mechanism of cell-growth inhibition, further experiments were performed. Both apoptosis and cell-cycle arrest were found to be involved. Apoptosis was suggested to be related to the regulation of the bcl-2 gene expression, dependent on the Gquadruplex stabilisation. ${ }^{97}$ However, the apoptotic pathway activation and the binding mode with G-quadruplex DNA still need further elucidations. Similar findings were reported the following year, in 2014, by Zhang and co-workers. ${ }^{98}$ In this work, they observed a greater inhibitory activity against MDA-MB-231 expressed by complex 27 (showed in Figure 7) compared with cisplatin, with $\mathrm{IC}_{50}=16.3 \pm 2.6 \mu \mathrm{M}$ and $\mathrm{IC}_{50}=36.1 \pm 1.9 \mu \mathrm{M}$ for complex $\mathbf{2 7}$ and cisplatin, respectively. Further studies prompted these scientists to suggest a correlation between the induced apoptosis observed and the stabilisation of G-quadruplex conformation of c-myc oncogene promoter via groove binding mode which led to the down-regulated expression of c-myc. ${ }^{98} \mathrm{~A}$ detailed mechanism of action is still under investigation but these findings suggests complex $\mathbf{2 7}$ as a potential apoptosis inducer characterized by a low toxicity against healthy HAcat cells. ${ }^{98}$

Moreover, during the same year, Srishailam and co-workers explored three new Ru(II) polypyridyl complexes, namely $\left[\right.$ Ru(phen) ${ }_{2}$ ptip $]\left(\mathrm{ClO}_{4}\right)_{2} \quad$ (28), $\quad[\text { Ru(bpy })_{2}$ ptip $]\left(\mathrm{ClO}_{4}\right)_{2} \quad$ (29) and $\left[\mathrm{Ru}(\mathrm{dmb})_{2}\right.$ ptip $]\left(\mathrm{ClO}_{4}\right)_{2} \quad(\mathbf{3 0}) .^{110}$ These complexes showed considerable antibacterial activity against $S$. aureus and $E$. coli at 1 $\mathrm{mg} / \mathrm{mL}$ and $0.5 \mathrm{mg} / \mathrm{mL}$ concentrations. The in vitro cytotoxicity was 


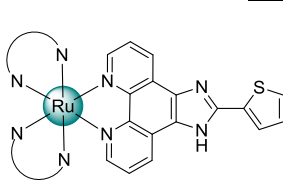

25,26

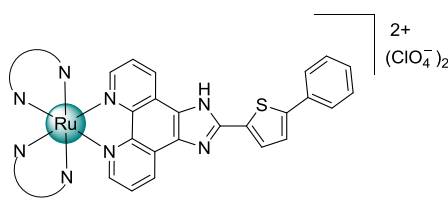

28-30

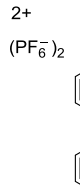

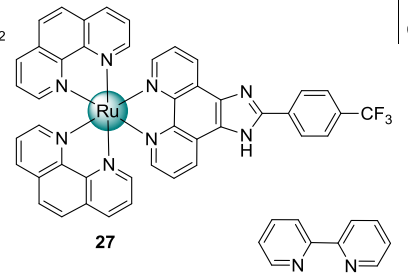

25, 29: bpy
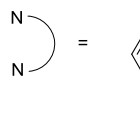

$\mathrm{Me}$

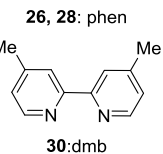

Fig. 7. Structures of $\left[R u(b p y)_{2}(\right.$ tip $\left.)\right]\left(P_{6}\right)_{2}(25)$, $\left[R u(\text { phen })_{2}(\right.$ tip $\left.)\right]\left(P F_{6}\right)_{2}(26)$ and $\left[\mathrm{Ru}(\text { phen })_{2}(\mathrm{p}\right.$-tFMPIP) $]\left(\mathrm{ClO}_{4}\right)_{2}$

(27), $\quad\left[\mathrm{Ru}(\text { phen })_{2}\right.$ ptip $]\left(\mathrm{ClO}_{4}\right)_{2}$

(28),

$\left[\mathrm{Ru}(\mathrm{bpy})_{2}\right.$ ptip $]\left(\mathrm{ClO}_{4}\right)_{2}(\mathbf{2 9})$ and $\left[\mathrm{Ru}(\mathrm{dmb})_{2} \mathrm{ptip}\right]\left(\mathrm{ClO}_{4}\right)_{2}(\mathbf{3 0})$.

against HeLa tumour cells. The compounds were found to be toxic and the authors suggested that the observed toxicity was related to DNA interaction. ${ }^{110}$ Confocal microscopy studies demonstrated that complexes 28-30 gradually penetrated the nucleus.

Between 2015 and 2016, Deepika and co-workers investigated several types of $\mathrm{Ru}(\mathrm{II})$ polypyridyl complexes. ${ }^{[99,100]}$ They first designed a new ligand named CNPFIP. Then, three complexes carrying this ligand, namely ([Ru(phen) $\left.{ }_{2} \mathrm{CNPFIP}\right]\left(\mathrm{ClO}_{4}\right)_{2}$ (31), $\left[\mathrm{Ru}(\mathrm{bpy})_{2} \mathrm{CNPFIP}\right]\left(\mathrm{ClO}_{4}\right)_{2}(32)$ and $\left[\mathrm{Ru}(\mathrm{dmb})_{2} \mathrm{CNPFIP}\right]\left(\mathrm{ClO}_{4}\right)_{2}$ shown in Figure 8 were investigated as antimicrobial and

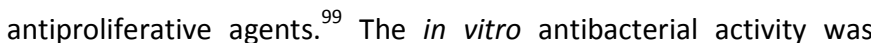
tested against E. coli (Gram-negative) and S. aureus (Gram-positive) bacteria. All three complexes showed higher activity against $S$. aureus than $E$. coli with complex 31 being the most active. Increasing the lipophilicity of the complexes, in fact, led to better permeation through the lipid layer of the bacterial membrane and thus higher activity. ${ }^{99}$ None of these complexes showed higher activity than the positive control Ampicillin. In addition, the in vitro cytotoxicity of the complexes was tested against HeLa cells using cisplatin as positive control. ${ }^{99}$ The same trend observed before (during the antimicrobial experiments) was found leading to compound $\mathbf{3 3}$ being the least active. In this case too, the positive control cisplatin was the most active compound tested $\left(\mathrm{IC}_{50}=35.51\right.$ $\mu \mathrm{M}, 36.74 \mu \mathrm{M}, 40.38 \mu \mathrm{M}$ and $4.52 \mu \mathrm{M}$, respectively for 31, 32, 33 and cisplatin). ${ }^{99}$ Later, the same scientists examined two new complexes, namely $\left[\mathrm{Ru}(\text { phen })_{2} \mathrm{bppp}\right]\left(\mathrm{ClO}_{4}\right)_{2}$ and $\left[\mathrm{Ru}(\text { phen })_{2} 7-\mathrm{Br}-\right.$ antimicrobial activity was tested against the same bacteria $\left(\mathrm{C}_{4}^{-}\right)_{2}$ mentioned above. In this case, the complexes showed higher activity against E.coli than S. aureus but in both cases still lower than ampicillin. ${ }^{100}$ Microscopy studies revealed that complexes 34 and 35 can be up taken from HeLa cells and accumulate in the nuclei. The in vitro toxicity on cancer cell lines, on the other hand, was tested against HeLa, Du145 and A549 cell lines. Both complexes displayed moderate cytotoxic activity against all tumour cell lines. ${ }^{100}$ More precisely, they were found to be slightly more effective against the HeLa cell line with $34\left(\mathrm{IC}_{50}=32.0 \pm 1.20 \mu \mathrm{M}\right)$ showing relatively higher cytotoxicity than $35\left(\mathrm{IC}_{50}=35.0 \pm 1.56\right.$ $\mu \mathrm{M})$. In all cases, the $\mathrm{IC}_{50}$ values were found to be higher than cisplatin. $^{100}$

\subsection{Mechanisms of action not involving direct interactions with}

\section{DNA}

To the best of our knowledge, the first study since the work by Dwyer and co-workers suggesting the exclusion of direct interactions of Ru(II) polypyridyl complexes with DNA in cell death was reported in 2008 by Schatzschneider and co-workers. ${ }^{111}$ In this study, these scientists investigated the cell growth inhibitory potency against two human cancer cell lines (HT-29 and MCF-7) of a series of $\mathrm{Ru}(\mathrm{II})$ polypyridyl complexes with varying degrees of extension of the aromatic ligand in order to correlate the lipophilicity of a compound with its cytotoxicity. ${ }^{111}$ This work showed that the cellular uptake was directly correlated with the size of the ligand. Inter alia, more lipophilic ligands led to greater $\mathrm{Ru}$ (II) concentration levels in cells. ${ }^{111}$ This statement was in complete agreement with that previously
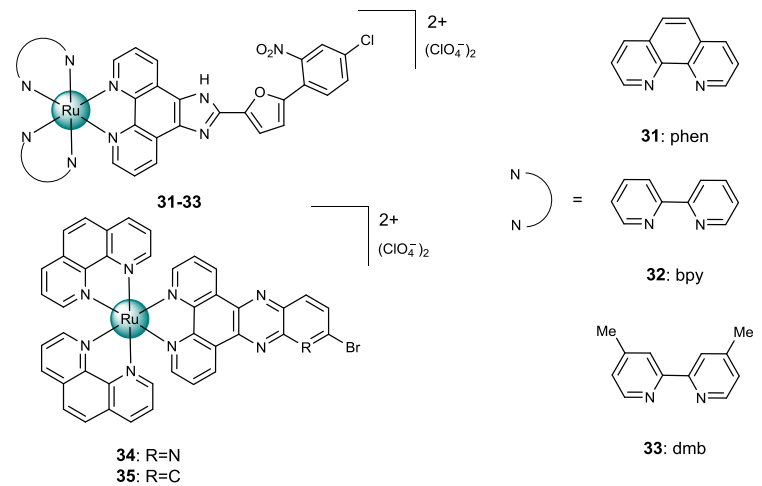

Fig. 8. Structures of $\left[\mathrm{Ru}(\text { phen })_{2} \mathrm{CNPFIP}\right]\left(\mathrm{ClO}_{4}\right)_{2}(\mathbf{3 1})$, $\left[\mathrm{Ru}(\mathrm{bpy})_{2} \mathrm{CNPFIP}\right]\left(\mathrm{ClO}_{4}\right)_{2}$ 
(32), $\quad\left[\mathrm{Ru}(\mathrm{dmb})_{2} \mathrm{CNPFIP}\right]\left(\mathrm{ClO}_{4}\right)_{2} \quad$ (33), $\quad\left[\mathrm{Ru}(\text { phen })_{2} \mathrm{bppp}\right]\left(\mathrm{ClO}_{4}\right)_{2} \quad$ (34) and [Ru(phen) $\left.{ }_{2} 7-\mathrm{Br}-\mathrm{dppz}\right]\left(\mathrm{ClO}_{4}\right)_{2}$ (35).

demonstrated on structurally similar $R u(I I)$ polypyridyl complexes. ${ }^{112}$ Moreover, the authors pointed out that greater cellular accumulation resulted in greater cytotoxicity on both cell lines. In particular, $\left[\mathrm{Ru}(\mathrm{bpy})_{2}(\mathrm{dppn})\right] \mathrm{Cl}_{2}(36$, Figure 9), which was the complex carrying the ligand with the greater aromatic surface area considered in this work, showed the most significant antiproliferative activity with $\mathrm{IC}_{50 \mathrm{~s}}<10 \mu \mathrm{M}$, values which are comparable to that of cisplatin under identical conditions. ${ }^{111}$ The mechanism of action was suggested to be related to the modification of cell membrane function and cell adhesion properties. ${ }^{111}$ This observation was in contrast with the accustomed focus on the DNA intercalative properties of such compounds.

One year later, Gao and co-workers showed that the antitumor activity of Ru(II) polypyridyl complexes must be related to different mechanisms than only DNA intercalation. ${ }^{113}$ In this work, these researchers designed and synthesised different complexes in order to improve the DNA-binding capability of their Ru(II) complexes by introducing electropositive pendants to the ancillary ligand or by increasing their intercalative aromatic surface (complexes 37-40 in Figure 9). The authors then tested the activity of these compounds as inhibitors of DNA transcription, which is involved in the mechanism of action for modifications mentioned above. They improved the DNA binding ability of their complexes, which led to a direct, positive correlation with the inhibition of DNA transcription. ${ }^{113}$ However, no clear trend was observed between the DNA binding ability of the complexes and their antitumor activity,

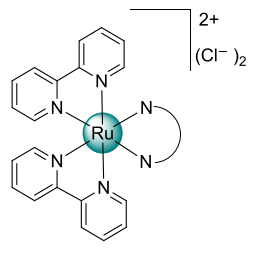

36

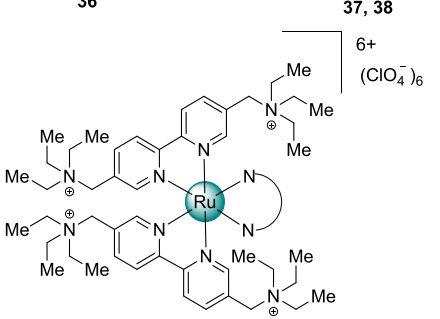

39, 40
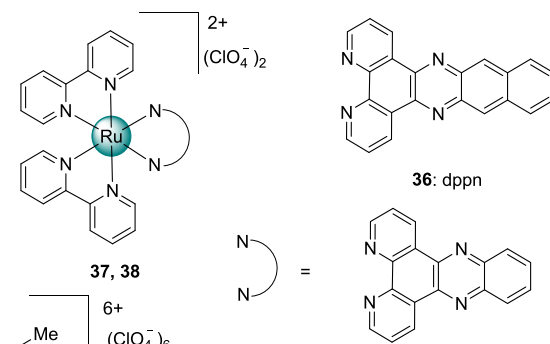

37, 39: dppz

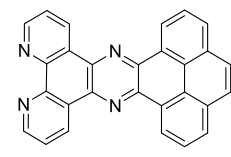

38, 40: pdppz

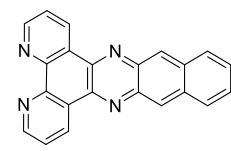

36: dppn
Fig. 9. Structures of $\left[\mathrm{Ru}(\mathrm{bpy})_{2}(\mathrm{dppn})\right](\mathrm{Cl})_{2}(36),\left[\mathrm{Ru}(\mathrm{bpy})_{2}(\mathrm{dppz})\right]\left(\mathrm{ClO}_{4}\right)_{2}(37)$,
$\left[\mathrm{Ru}(\mathrm{bpy})_{2}(\mathrm{pdppz})\right]\left(\mathrm{ClO}_{4}\right)_{2} \quad(\mathbf{3 8}), \quad\left[\mathrm{Ru}\left(\mathrm{R}_{2} \mathrm{bpy}\right)_{2}(\mathrm{dppz})\right]\left(\mathrm{ClO}_{4}\right)_{6}$

(39), $\left[\mathrm{Ru}\left(\mathrm{R}_{2} \mathrm{bpy}\right)_{2}(\mathrm{pdppz})\right]\left(\mathrm{ClO}_{4}\right)_{6}(40)$.

indicating that DNA transcription inhibition must not be the only process involved. ${ }^{113}$ The unlikely DNA involvement in the mechanism of action of certain Ru(II) polypyridyl complexes was also confirmed by Zava and co-workers. ${ }^{114}$ They explored the cellular uptake mechanism and the cytotoxicity of a class of $\left[\mathrm{Ru}(\mathrm{bpy})_{3}\right] \mathrm{Cl}_{2}$ complexes, where the bpy group was derivatised with functionalities to provide different lipophilicities. Figure 6 shows complexes 41-45 which carry respectively bpy, dmb, dmab, dmcb and dmob ligands. Microscopy studies showed that subcellular localisation varies greatly (i.e., plasma membrane, cytoplasmic organelles). Since accumulation in the cell nucleus was not observed for any of the compounds, the DNA damage associated with cell death was strongly questioned for these types of compounds. ${ }^{114}$ Over the years, different types of mechanism of cytotoxic action started to be proposed. Among them, the apoptotic cell death through the activation of the mitochondrial dysfunctional pathway started to arise as a main cause of cytotoxicity exerted by Ru(II) polypyridyl complexes. ${ }^{[115-119]}$ In 2010, combinatorial coordination chemistry followed by cytotoxicity screening allowed the discovery of a new antiproliferative complex $\left(\left[R u\left(t B u_{2} \text { bpy }\right)_{2}(\right.\right.$ phox $\left.)\right] \mathrm{PF}_{6}(46$, Figure 10$) .{ }^{117}$ After a brief structureactivity relationship, Meggers and co-workers demonstrated that complex 46 showed the highest cytotoxicity when compared with the other tris-heteroleptic complexes tested.

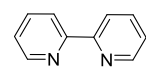

41: bpy
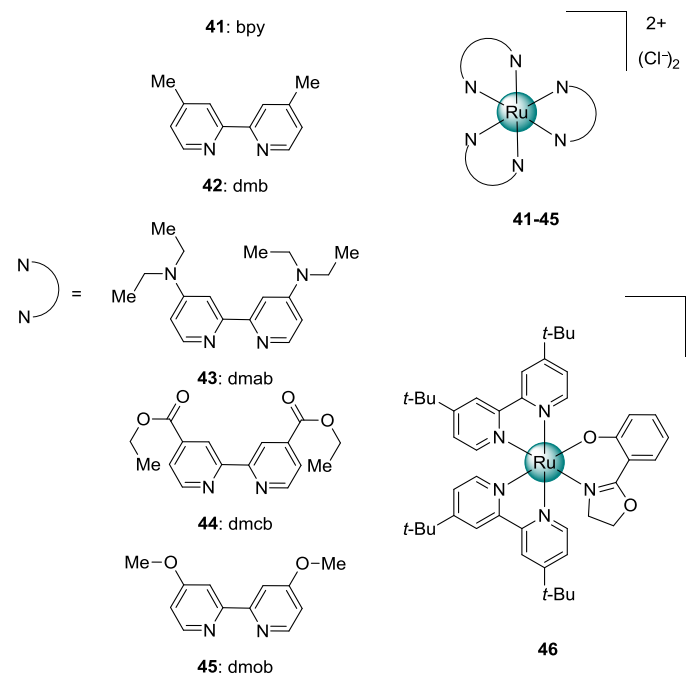

$41-45$
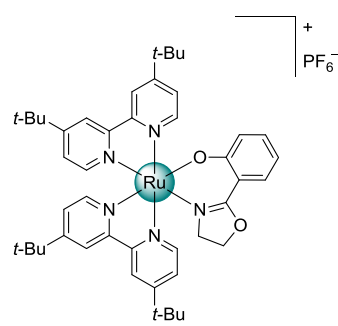
Fig. 10. Structures of $\left[\mathrm{Ru}(\mathrm{bpy})_{3}\right] \mathrm{Cl}_{2}$ and its derivatives (41-45) and $\left(\left[R u\left(t B u_{2} b p_{2}\right)_{2}(\right.\right.$ phox $\left.)\right] P F_{6}(46)$.

Its cytotoxicity was tested in HeLa cells and displayed $\mathrm{LC}_{50}$ values of 1.3 $\mu \mathrm{M}$ and $0.3 \mu \mathrm{M}$ after incubation for 24 and $72 \mathrm{~h}$ respectively, where the $\mathrm{LC}_{50}$ is the lethal concentration required to kill $50 \%$ of the cell population. ${ }^{117}$ Afterwards, the antiproliferative and apoptotic properties of the complex were confirmed in BJAB cells. The strong reduction of the mitochondrial membrane potential registered is a clear sign of a programmed cell death pathway activation. ${ }^{120}$ Interestingly, complex $\mathbf{4 6}$ was able to affect the viability of BJAB cells after $24 \mathrm{~h}$ incubation in a dose-dependent manner starting from very low concentrations $(100 \mathrm{nM}){ }^{117}$ It is worth noting that $\mathrm{Ru}(\mathrm{II})$ complexes with chelating ligands containing both nitrogen and oxygen or nitrogen and sulphur as donor atoms were already investigated presenting interesting biological activities as anticancer and antibacterial agents. ${ }^{[121,122]}$

During the same year Tan and co-workers demonstrated, for the first time, that $\mathrm{Ru}(\mathrm{II})$ polypyridyl complexes with $\beta$-carboline alkaloids could simultaneously induce autophagy and apoptosis in HeLa cells through a ROS-mediated mechanism (ROS= reactive oxygen species), which led to mitochondrial dysfunction. ${ }^{116}$ However, DNA could be the primary target of this nuclear permeable complex since the cytotoxicity of the complexes directly correlated with their DNA binding affinity. ${ }^{116}$ Once again, the antiproliferative character of the complexes was in agreement with their intracellular uptake, which was itself dependent on the lipophilicity. In this case, the $\left[R u(D I P)_{2}(1-P y-\beta C)\right]\left(P F_{6}\right)_{2}$ (47, Figure 11) was the complex carrying the most extended $\pi$-system and, as expected, showed the strongest cytotoxicity. ${ }^{116}$

A year later, in 2011, the same scientists investigated the cytotoxicity of three different Ru(II) polypyridyl complexes of the general formula $\left[\mathrm{Ru}(\mathrm{N}-\mathrm{N})_{2}(\text { Norharman })_{2}\right]\left(\mathrm{SO}_{3} \mathrm{CF}_{3}\right)_{2}$, where $\mathrm{N}-\mathrm{N}=$ bpy (48), phen (49), DIP (50), respectively, as shown in Figure 11. Norharman is a naturally occurring $\beta$-carboline alkaloid. ${ }^{119}$ The in vitro cytotoxicity of these complexes was evaluated against three cancer cell lines HepG2, HeLa, MCF-7 using cisplatin as a control. The greatest cytotoxicity was exhibited by complex $\mathbf{5 0}$ which had an $\mathrm{IC}_{50}=0.92 \pm 0.1 \mu \mathrm{M}, \mathrm{IC}_{50}=0.74 \pm 0.21 \mu \mathrm{M}$ and $\mathrm{IC}_{50}=2.30 \pm 0.5 \mu \mathrm{M}$ for HepG2, HeLa and MCF-7, respectively. ${ }^{119}$ These values were found to be much lower than that of cisplatin $\left(I C_{50}=20.2 \pm 3.6 \mu \mathrm{M}\right.$, $\mathrm{IC}_{50}=16.7 \pm 2.5 \mu \mathrm{M}$ and $\mathrm{IC}_{50}=35.2 \pm 4.2 \mu \mathrm{M}$, respectively) and of Norharman itself $\left(\mathrm{IC}_{50}=178.3 \pm 9.1 \mu \mathrm{M}, \mathrm{IC}_{50}=185.3 \pm 7.9 \mu \mathrm{M}\right.$ and
$\mathrm{IC}_{50}=167.7 \pm 8.3 \mu \mathrm{M}$, respectively) indicating that the coordination to the $\mathrm{Ru}(\mathrm{II})$ polypyridyl moiety significantly improves the anticancer activity. Moreover, consistently with their previous work, ${ }^{116}$ they observed a direct correlation between lipophilicity, cellular uptake efficiency and cytotoxicity. ${ }^{119}$ It was shown that the apoptosis induced by complexes 48-50 was related to mitochondrial dysfunction and ROS accumulation. However, as discussed above, $^{116}$ DNA could also be the primary target of the compounds. ${ }^{119}$ As demonstrated by confocal microscopy studies the nuclear permeability was also confirmed for complex $50 .^{119}$ This phenomenon was speculated to be related to $\beta$-carboline since other complexes containing this moiety were already found to pass through the nuclear envelope. ${ }^{[116,123]}$

Taking into account the above-mentioned studies, in 2012, our group in collaboration with the teams of Ferrari and Spiccia reported a detailed study of the in vitro behaviour of four complexes, namely $\left[\mathrm{Ru}(\mathrm{bpy})_{2}(\mathrm{CppH})\right]\left(\mathrm{PF}_{6}\right)_{2}(\mathbf{5 1})$, $\left[\mathrm{Ru}(\mathrm{bpy})_{2}(\mathrm{Cpp}-\mathrm{NH}-\right.$ $\mathrm{Hex}-\mathrm{COOH})]\left(\mathrm{PF}_{6}\right)_{2} \quad$ (52), $\quad\left[\mathrm{Ru}(\mathrm{dppz})_{2}(\mathrm{CppH})\right]\left(\mathrm{PF}_{6}\right)_{2} \quad$ (53), and $\left[\mathrm{Ru}(\mathrm{dppz})_{2}(\mathrm{Cpp}-\mathrm{NH}-\mathrm{Hex}-\mathrm{COOH})\right]\left(\mathrm{PF}_{6}\right)_{2} \quad(\mathbf{5 4})($ Figure 12$) .^{124}$ Their cytotoxicity was investigated against the cancerous HeLa, MCF-7, U2OS, A2780, A2780-CP70 cell lines and the non-cancerous MRC-5 cell line as a control. In this case, the exclusion of nuclear DNA from the mechanism of action responsible for the cytotoxicity was demonstrated. ${ }^{124}$ Specifically, the bpy-containing $\mathrm{Ru}(\mathrm{II})$ polypyridyl complexes (51 and $\mathbf{5 2}$ ) were found to be non-cytotoxic contrary to the dppz- containing Ru(II) polypyridyl complexes (53 and 54) which were found to be cytotoxic towards all the six cell lines tested. Inter alia, complex $\left[\mathrm{Ru}(\mathrm{dppz})_{2}(\mathrm{CppH})\right]\left(\mathrm{PF}_{6}\right)_{2}$ (53) expressed the best therapeutic profile

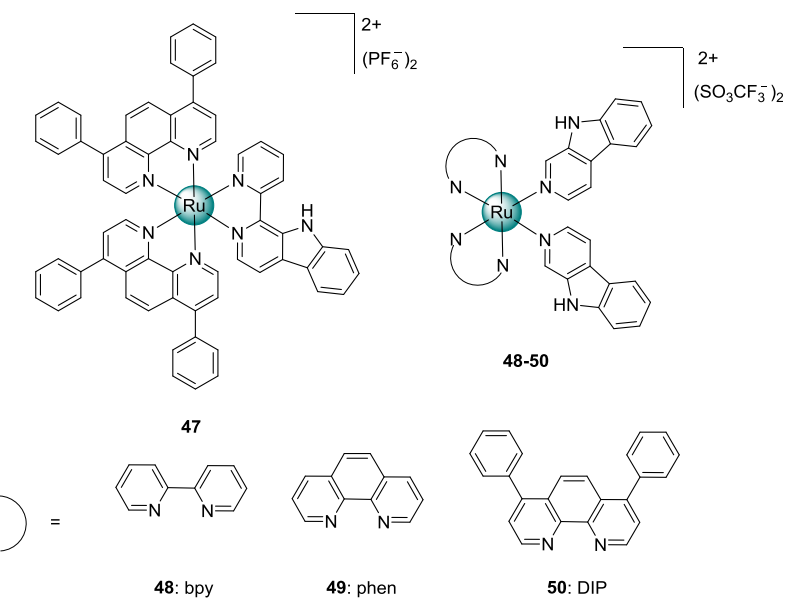

Fig. 11. Structures of, $\left[R u(D I P)_{2}(1-P y-\beta C)\right]\left(P F_{6}\right)_{2}$ 
$\left[\mathrm{Ru}(\text { bpy })_{2}(\text { Norharman })_{2}\right]\left(\mathrm{SO}_{3} \mathrm{CF}_{3}\right)_{2} \quad$ (48), $\quad\left[\mathrm{Ru}(\text { phen })_{2}(\text { Norharman })_{2}\right]\left(\mathrm{SO}_{3} \mathrm{CF}_{3}\right)_{2}$ (49), $\left[\mathrm{Ru}(\mathrm{DIP})_{2}(\text { Norharman })_{2}\right]\left(\mathrm{SO}_{3} \mathrm{CF}_{3}\right)_{2}$ (50).

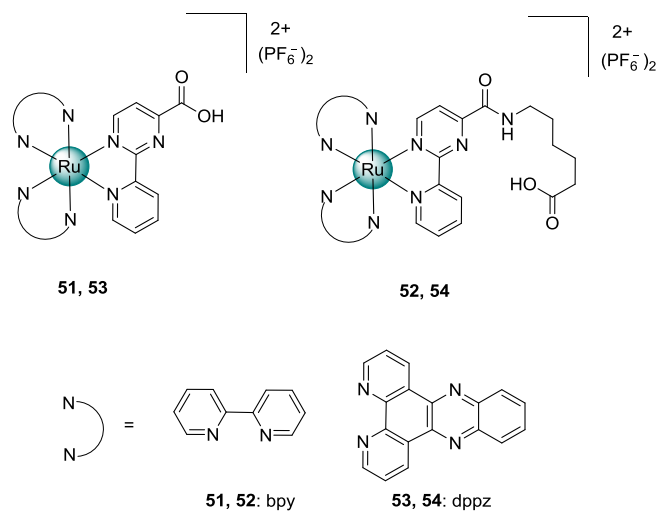

Fig. 12. Structures of $\left[R u(b p y)_{2}(C p p H)\right]\left(\mathrm{PF}_{6}\right)_{2}(51),\left[R u(b p y)_{2}(\mathrm{Cpp}-\mathrm{NH}-\mathrm{Hex}-\right.$ $\mathrm{COOH})]\left(\mathrm{PF}_{6}\right)_{2}(\mathbf{5 2}),\left[\mathrm{Ru}(\mathrm{dppz})_{2}(\mathrm{CppH})\right]\left(\mathrm{PF}_{6}\right)_{2}(\mathbf{5 3})$, and $\left[\mathrm{Ru}(\mathrm{dppz})_{2}(\mathrm{Cpp}-\mathrm{NH}-\right.$ $\mathrm{Hex}-\mathrm{COOH})]\left(\mathrm{PF}_{6}\right)_{2}(\mathbf{5 4})$.

with $\mathrm{IC}_{50}$ values comparable with cisplatin in cancerous cell lines and lower toxicity toward the healthy cell line. ${ }^{124}$ Moreover, cell localisation studies demonstrated the accumulation of compound 53 in mitochondria. On the contrary, complex 54 was found to accumulate in the cell nucleus. Further experimental studies brought our team to exclude the presence of ROS involvement in the mode of cell death of $\mathbf{5 3}$ and to confirm apoptosis as the mode of cell death induced by a mitochondria related pathway. ${ }^{124}$

In 2013, Jiang and co-workers revived the same mechanism of action involving the production of ROS species, as already described above with the compounds of Tan and co-workers. ${ }^{[116,125]}$ In this work, they demonstrated that complexes $\left[\mathrm{Ru}(\text { phen })_{2}(\mathrm{adppz})\right]\left(\mathrm{ClO}_{4}\right)_{2}$ and $\left[\mathrm{Ru}(\mathrm{DIP})_{2}(\mathrm{adppz})\right]\left(\mathrm{ClO}_{4}\right)_{2}$ (55 and 56, Figure 13) can enter into the cytoplasm and accumulate in the nucleus. ${ }^{125}$ They exerted their in vitro cytotoxicity against BEL-7402 cell line through activation of caspase 7, upregulation of proapoptotic protein and ROS-mediated mitochondrial dysfunction pathways $\left(I C_{50}=23.5 \pm 2.3 \mu \mathrm{M}, \quad I C_{50}=\right.$ $12.7 \pm 1.1 \mu \mathrm{M}$ and $\mathrm{IC}_{50}=11.5 \pm 1.2 \mu \mathrm{M}$ for 55,56 and cisplatin respectively). ${ }^{125}$

More or less the same observations were made by Chao and coworkers during the same year. ${ }^{126}$ In this work, they analysed the cytotoxicity of four different complexes, namely $\left[\mathrm{Ru}(\mathrm{bpy})_{2}(\mathrm{PAIDH})\right]\left(\mathrm{ClO}_{4}\right)_{2} \quad(\mathbf{5 7} \quad$ in Figure 13), $\left[\mathrm{Ru}(\text { phen })_{2}(\mathrm{PAIDH})\right]\left(\mathrm{ClO}_{4}\right)_{2} \quad(58$ in Figure 13$), \quad[\mathrm{Ru}(4,7-$ dmp $\left.)_{2}(\mathrm{PAIDH})\right]\left(\mathrm{ClO}_{4}\right)_{2}\left(59\right.$ in Figure 13), and $\left[\mathrm{Ru}(\mathrm{DIP})_{2}(\mathrm{PAIDH})\right]\left(\mathrm{ClO}_{4}\right)_{2}$ (60 in Figure 13). ${ }^{126}$ Compounds 57 and 58 were already reported in a previous study by the same authors, where they focused their attention on DNA-binding properties of Ru complexes, ${ }^{127}$ while complexes 59 and 60 were investigated here for the first time. Cytotoxicity studies were performed against HeLa, A549, BEL-7402, HepG2 and LO2 cells using cisplatin as a control. ${ }^{126}$ From these studies, a consistency between the cytotoxicity and the cellular uptake properties of the compounds was unveiled. Complex 60, which carries the most lipophilic ligand, expresses the highest cellular uptake and cytotoxicity. ${ }^{126}$ It induces HeLa cells apoptosis through the activation of mitochondrial dysfunctional pathway with $\mathrm{IC}_{50}=7.9 \pm 0.7 \mu \mathrm{M}$, while cisplatin has $\mathrm{IC}_{50}=17.8 \pm 2.6 \mu \mathrm{M}$. All the complexes express better selectivity than cisplatin against the healthy cell line $\mathrm{LO} 2\left(\mathrm{IC}_{50}=77.4 \pm 4.3 \mu \mathrm{M}\right.$ and $\mathrm{IC}_{50}=11.2 \pm 0.6 \mu \mathrm{M}$, respectively for complex 60 and cisplatin). ${ }^{126}$ Moreover, complex 60 was shown to accumulate preferentially in mitochondria. These findings suggest complex 60 as a potent and selective chemotherapeutic agent.

Between 2013 and 2014, Xie and co-workers focused their attention on the cytotoxicity of $\mathrm{Ru}(\mathrm{II})$ polypyridyl complexes with ligands containing nitro-, amino- or hydroxyl group. ${ }^{[128-130]}$ First, they considered four $\mathrm{Ru}(\mathrm{II})$ polypyridyl complexes, namely $\left[\mathrm{Ru}(\text { bpy })_{2}(\mathrm{NHPIP})\right]\left(\mathrm{ClO}_{4}\right)_{2} \quad(\mathbf{6 1}), \quad\left[\mathrm{Ru}(\text { phen })_{2}(\mathrm{NHPIP})\right]\left(\mathrm{ClO}_{4}\right)_{2}$ (62), $\left[\mathrm{Ru}(\mathrm{bpy})_{2}(\mathrm{AHPIP})\right]\left(\mathrm{ClO}_{4}\right)_{2}(63)$, and $\left[\mathrm{Ru}(\text { phen })_{2}(\mathrm{AHPIP})\right]\left(\mathrm{ClO}_{4}\right)_{2}$ (64) shown in Figure $14 .{ }^{129}$ Fluorescence microscopy studies demonstrated that these complexes ultimately accumulated in the nucleus after being taken up by the cells. The in vitro cytotoxicity of these complexes was then tested against four cancer cell lines, namely BEL-7402, HeLa, MG-63, and MCF-7. ${ }^{129}$ It was confirmed once again that the complex carrying the more lipophilic ancillary ligands is more cytotoxic. Moreover, the results suggested that the amino group could also enhance the cytotoxicity leading to complex 64 being the most active. ${ }^{129}$

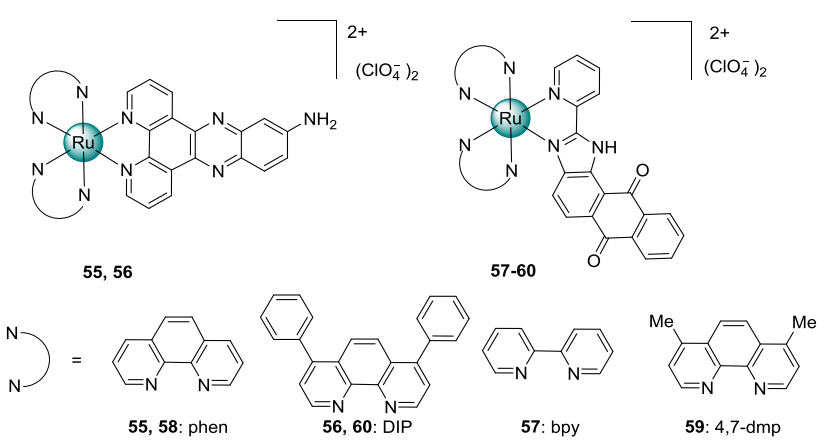

Fig. 13. Structures of $\left[\mathrm{Ru}(\text { phen })_{2}(\operatorname{adppz})\right]\left(\mathrm{ClO}_{4}\right)_{2}(55),\left[\mathrm{Ru}(\mathrm{DIP})_{2}(\operatorname{adppz})\right]\left(\mathrm{ClO}_{4}\right)_{2}$ 
(56), $\left[\mathrm{Ru}(\mathrm{bpy})_{2}(\mathrm{PAIDH})\right]\left(\mathrm{ClO}_{4}\right)_{2}$ (57), $\left[\mathrm{Ru}(\text { phen })_{2}(\mathrm{PAIDH})\right]\left(\mathrm{ClO}_{4}\right)_{2}$ (58), $[\mathrm{Ru}(4,7-$ $\left.\mathrm{dmp})_{2}(\mathrm{PAIDH})\right]\left(\mathrm{ClO}_{4}\right)_{2}(59)$, and $\left[\mathrm{Ru}(\mathrm{DIP})_{2}(\mathrm{PAIDH})\right]\left(\mathrm{ClO}_{4}\right)_{2}(\mathbf{6 0})$.

These researchers then investigated two other analogues with a more lipophilic ancillary ligand. Complexes $[\mathrm{Ru}(2,9-$ $\left.\mathrm{dmp})_{2}(\mathrm{NHPIP})\right]\left(\mathrm{ClO}_{4}\right)_{2}$ (65) and $\left[\mathrm{Ru}(2,9-\mathrm{dmp})_{2}(\mathrm{AHPIP})\right]\left(\mathrm{ClO}_{4}\right)_{2}$ (66, Figure 14) were tested towards the same cell lines and a small improvement in cytotoxicity was noted $\left(\mathrm{IC}_{50}=13.6 \pm 1.2 \mu \mathrm{M}(64)\right.$ and $\mathrm{IC}_{50}=5.4 \pm 0.5 \mu \mathrm{M}(66)$ in BEL-7402). ${ }^{128} \mathrm{~A}$ reduction of the mitochondrial potential and an increase of ROS species upon treatment of the cells with the $\mathrm{Ru}(\mathrm{II})$ complexes were detected, indicating activation of apoptosis through the mitochondrial pathway. ${ }^{128}$ Further studies on complexes carrying either more lipophilic or functionalised ligands, unfortunately, led to no significant improvement in cytotoxicity towards A549, BEL-7402, HeLa and MG-63 cells. ${ }^{[130,131]}$ In 2014, Du and co-workers showed that similar complexes such as $\left[\mathrm{Ru}(\text { phen })_{2}(p\right.$-tFPIP $\left.)\right]\left(\mathrm{ClO}_{4}\right)_{2} \quad(67$ in Figure 14) accumulated in mitochondria and were able to induce mitochondria-mediated apoptosis in MG-63 cells by mitochondrial fragmentation. ${ }^{132}$ In 2014, Jiang and co-workers investigated the biological potential of $\mathrm{Ru}(\mathrm{II})$ polypyridyl complexes carrying new ligands, namely dmdppz and addppn to prepare $\left[\mathrm{Ru}(\text { phen })_{2}(\mathrm{dmdppz})\right]\left(\mathrm{ClO}_{4}\right)_{2}$ and its derivatives (68-71), and $\left[\mathrm{Ru}(\text { phen })_{2}\right.$ (addppn) $]\left(\mathrm{ClO}_{4}\right)_{2}(\mathbf{7 2}) .{ }^{[133,134]}$ In the case of complexes 68 71, no improvement in cytotoxicity compared to cisplatin was
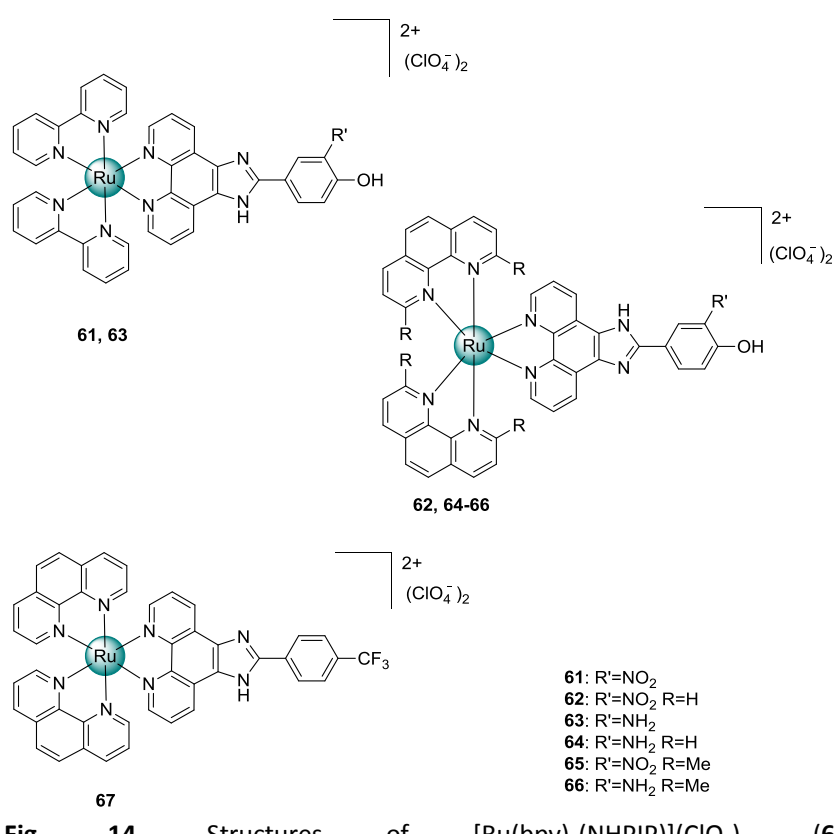

Fig. 14. Structures of $\left[\mathrm{Ru}(\mathrm{bpy})_{2}(\mathrm{NHPIP})\right]\left(\mathrm{ClO}_{4}\right)_{2}$ $\left[\mathrm{Ru}(\text { phen })_{2}(\mathrm{NHPIP})\right]\left(\mathrm{ClO}_{4}\right)_{2} \quad(62), \quad\left[\mathrm{Ru}(\mathrm{bpy})_{2}(\mathrm{AHPIP})\right]\left(\mathrm{ClO}_{4}\right)_{2}$

(61),

(63),
$\left[\mathrm{Ru}(\text { phen })_{2}(\mathrm{AHPIP})\right]\left(\mathrm{ClO}_{4}\right)_{2}(64),\left[\mathrm{Ru}(2,9-\mathrm{dmp})_{2}(\mathrm{NHPIP})\right]\left(\mathrm{ClO}_{4}\right)_{2}(65)$, $[\mathrm{Ru}(2,9-$ $\left.\mathrm{dmp})_{2}(\mathrm{AHPIP})\right]\left(\mathrm{ClO}_{4}\right)_{2}(66)$ and $\left[\mathrm{Ru}(\text { phen })_{2}(p\right.$-tFPIP) $]\left(\mathrm{ClO}_{4}\right)_{2}(67)$.

recorded on BEL-7402 cells. ${ }^{133}$ On the contrary, higher cytotoxicity than cisplatin was demonstrated for $\mathbf{7 2}{ }^{134}$ All the complexes (6872) increased the level of ROS and induced a decrease of the mitochondrial membrane potential. ${ }^{[133,134]}$ These results suggested the intrinsic ROS-mediated mitochondrial pathway as the determinant for the apoptosis of BEL-7402 cells. Moreover, programmed cell death induction was accompanied by the regulation of $\mathrm{Bcl}-2$ family proteins. ${ }^{[133,134]}$

Concurrently, $\mathrm{Yu}$ and co-workers proposed two new $\mathrm{Ru}(\mathrm{II})$ polypyridyl complexes with hydrophobic ancillary ligands which affect multiple targets simultaneously. ${ }^{135}$ In this work, these scientists investigated the anti-cancer effects and molecular mechanisms of complexes (shown in Figure 16), $\left[R u(b p y)_{2}(5-\right.$ idip) $]\left(\mathrm{ClO}_{4}\right)_{2} \quad$ (73) and $\left[\mathrm{Ru}(\text { phen })_{2}(5\right.$-idip) $]\left(\mathrm{ClO}_{4}\right)_{2} \quad$ (74). The cytotoxicity of these compounds was tested against HeLa, A549, A375, HepG2, Hep-2 and normal cell NIH/3T3 using cisplatin as a control. ${ }^{135}$ Complex $\mathbf{7 4}$ was found to have a good therapeutic profile since it has $I_{50}$ values comparable with cisplatin, especially against HeLa $\left(\mathrm{IC}_{50}=11.7 \pm 1.2 \mu \mathrm{M}\right.$ and $\mathrm{IC}_{50}=7.6 \pm 0.4 \mu \mathrm{M}$ for 74 and cisplatin, respectively). Both complexes can induce apoptosis through the activation of two different mechanisms. ${ }^{135}$ On one hand, the activation of the mitochondrial dysfunctional pathway and on the other the stabilisation of telomeric DNA through the formation of G-quadruplexes which denies the telomerase access, leading to apoptosis induction. ${ }^{135}$ Complex 74 accumulates first in lysosomes and then relocates with time within more sensitive organelles such as nucleus and chondriosome.

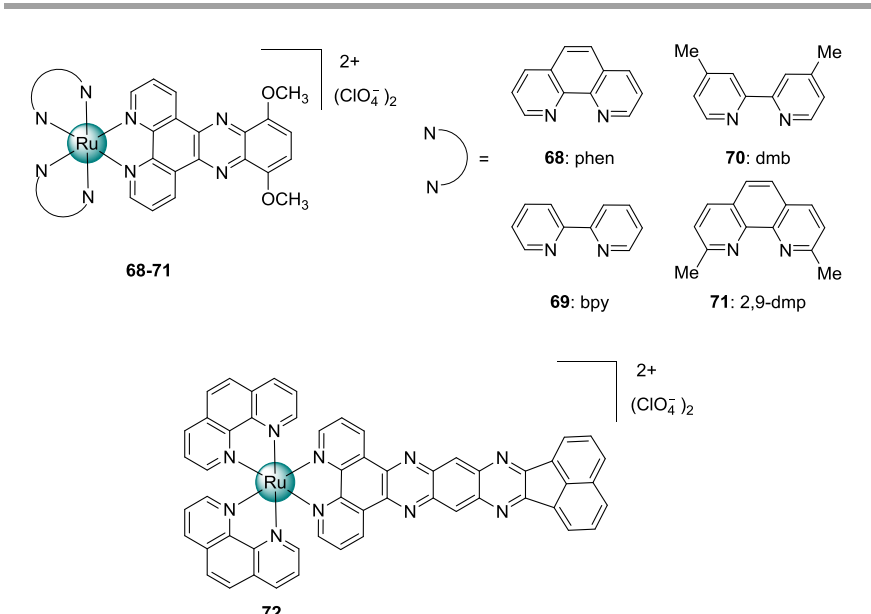

Fig. 15. Structures of $\left[\mathrm{Ru}(\mathrm{phen})_{2}(\mathrm{dmdppz})\right]\left(\mathrm{ClO}_{4}\right)_{2}$ and its derivatives (68-71), $\left[\mathrm{Ru}(\text { phen })_{2}\right.$ (addppn) $]\left(\mathrm{ClO}_{4}\right)_{2}(\mathbf{7 2})$. 


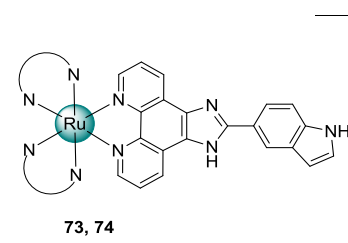

$\left(\mathrm{ClO}_{4}^{-}\right)_{2}$

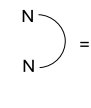

73,74

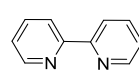

73: bpy

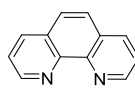

74: phen
Fig. 16. Structures of $\left[\mathrm{Ru}(\mathrm{bpy})_{2}(5\right.$-idip $\left.)\right]\left(\mathrm{ClO}_{4}\right)_{2}$ (73) and $\left[\mathrm{Ru}(\mathrm{phen})_{2}(5-\right.$ $\operatorname{idip})]\left(\mathrm{ClO}_{4}\right)_{2}(74)$.

Between 2014 and 2015, Mazuryk and co-workers proposed a new $\mathrm{Ru}(\mathrm{II})$ polypyridyl complex containing a nitroimidazole unit as an optical imaging, chemotherapeutic and anti-metastatic agent. ${ }^{[136,137]}$ Firstly, they found out that $\left[\mathrm{Ru}(\mathrm{DIP})_{2}(\right.$ bpy-2-nitrolm) $] \mathrm{Cl}_{2}$ (75 in Figure 17) targeted preferentially hypoxic cells. ${ }^{136}$ The rationale of this behaviour seems to be the trapping of the compound inside the cells as a consequence of the interaction between proteins and/or DNA and a derivative formed by the irreversible reduction of a nitroimidazole moiety under hypoxic conditions. ${ }^{[136,138]}$ Preliminary studies showed the applicability of complex 75 as an optical imaging and chemotherapeutic agent. In more detail, the complex can be used as a dye at concentrations lower than $1 \mu \mathrm{M}$, while at higher concentrations the growth inhibition starts to be consistent. ${ }^{136}$ The cytotoxicity of compound $\mathbf{7 5}$ was tested under normoxia and hypoxia. Preliminary data was obtained on A549 cell line showing a clear increment of the cytotoxicity under hypoxia $\left(\mathrm{LC}_{50}=11.8 \pm 1.2\right.$ $\mu \mathrm{M}$ under normoxic conditions and $\mathrm{LC}_{50}=7.7 \pm 0.4 \mu \mathrm{M}$ under $1 \%$ of oxygen). ${ }^{136}$ In a following paper, the scientists confirmed the cytotoxicity of $\mathbf{7 5}$. It was tested against 4T1 and A549 under normoxia and hypoxia, with or without serum leading to $I C_{50}$ values from 1.5 to $18.8 \mu \mathrm{M}^{137}$ Cisplatin was used as a control and showed lower cytotoxicity under the same conditions. Apoptosis was suggested to be a consequence of ROS generation. ${ }^{137}$ Confocal microscopy studies demonstrated accumulation of complex $\mathbf{7 5}$ in mitochondria. More interestingly, a distinct impact on cell adhesion and migration as well as an interesting effect on endothelial cell vasculature was recorded. ${ }^{137}$ On one hand, it was found that the compound tested favoured the adhesion of attached cells and disfavoured it in the case of unattached ones thus leading to promising anti-metastatic activity. ${ }^{137}$ On the other hand, it was suggested that Ru(II) polypyridyl complexes could affect the formation of new capillaries through the re-arrangement of endothelial cells leading to an improvement in blood perfusion. These findings gave the basis to consider $\mathrm{Ru}(\mathrm{II})$ polypyridyl complexes as interesting compounds for angiogenesis-based treatments. $^{137}$ Regulation of angiogenesis process (new blood vessels formation) is in fact a known powerful supporting strategy in cancer treatment. ${ }^{139}$

In 2015, Lai and co-workers examined the potential antiproliferative activity of $\left[\mathrm{Ru}(2,9-\mathrm{dmp})_{2}(\mathrm{pddppn})\right]\left(\mathrm{ClO}_{4}\right)_{2} \quad(76, \text { Figure } 17)^{140}$ Fluorescence microscopy studies showed that $\mathbf{7 6}$ accumulated in the nucleus. The in vitro cytotoxicity of the complex was evaluated against BEL-7402, HeLa, A549 and MG-63 cell lines. Complex 76 showed higher cytotoxicity than cisplatin in the cell lines tested except for HeLa where the $\mathrm{IC}_{50}$ value was found to be relatively similar $\left(9.0 \pm 0.8 \mu \mathrm{M}(76)\right.$ and $7.3 \pm 1.4 \mu \mathrm{M}$ (cisplatin)). ${ }^{140}$ Further experiments showed that $\mathbf{7 6}$ could induce apoptosis of cancer cells, enhance the ROS levels and reduce the potential of mitochondrial membrane. Moreover, complex 76 was found to up-regulate the levels of different caspases and to down-regulate the expression of some proteins belonging to the $\mathrm{Bcl}-2$ family. ${ }^{140}$ These findings suggested that $\left[\mathrm{Ru}(2,9-\mathrm{dmp})_{2}(\mathrm{pddppn})\right]\left(\mathrm{ClO}_{4}\right)_{2}$ induced apoptosis through an intrinsic ROS-mediated mitochondrial dysfunction pathway, which was accompanied by the regulation of $\mathrm{Bcl}-2$ family proteins. $^{140}$

One year later, Zhang and co-workers studied four new Ru(II) polypyridyl complexes, namley $\left.\mathrm{Ru}(\mathrm{dmb})_{2}(\mathrm{DQTT})\right]\left(\mathrm{ClO}_{4}\right)_{2}$ (77), $\left.\mathrm{Ru}(\mathrm{bpy})_{2}(\mathrm{DQTT})\right]\left(\mathrm{ClO}_{4}\right)_{2}$ (78), $\left.\mathrm{Ru}(\text { phen })_{2}(\mathrm{DQTT})\right]\left(\mathrm{ClO}_{4}\right)_{2} \quad$ (79) and $\left[\mathrm{Ru}(2,9-\mathrm{dmp})_{2}(\mathrm{DQTT})\right]\left(\mathrm{ClO}_{4}\right)_{2}(\mathbf{8 0})$ shown in Figure $18 .^{141}$ The in vitro cytotoxicity was evaluated against human BEL-7402, A549, HeLa, HepG-2 and MG-63 cancer cell lines. All complexes exhibited moderate cytotoxicity against $B E L-7402$ cell line $\left(\mathrm{IC}_{50}=31.8 \pm 1.0\right.$ $\mu \mathrm{M}, \quad I C_{50}=35.8 \pm 1.6 \mu \mathrm{M}, I_{50}=29.0 \pm 0.8 \mu \mathrm{M}, I_{50}=25.0 \pm 5.9 \mu \mathrm{M}$, respectively for 77-80). ${ }^{141}$ On the other hand, complexes 77-79

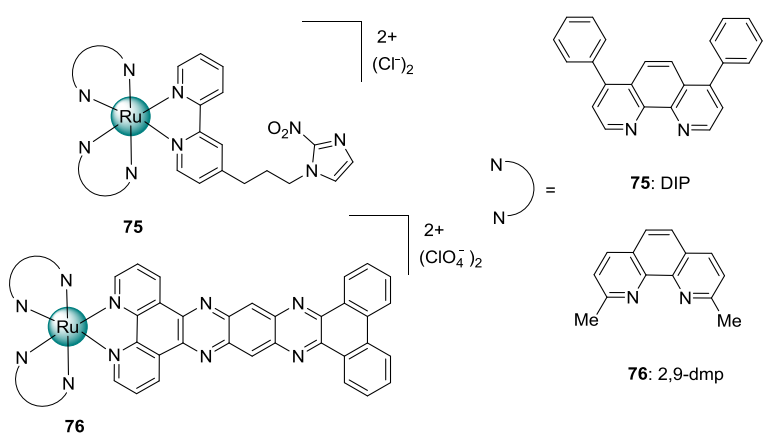

Fig. 17. Structures of $\left[\mathrm{Ru}(\mathrm{DIP})_{2}(\right.$ bpy-2-nitrolm $\left.)\right] \mathrm{Cl}_{2}$ (75) and $[\mathrm{Ru}(2,9$ $\left.\mathrm{dmp})_{2}(\mathrm{pddppn})\right]\left(\mathrm{ClO}_{4}\right)_{2}(76)$.

showed high cell growth inhibition in $A 549$ cells $\left(I_{50}=15.9 \pm 1.0\right.$ $\mu \mathrm{M}, \mathrm{IC}_{50}=41.8 \pm 2.1 \mu \mathrm{M}, \mathrm{IC}_{50}=16.4 \pm 0.7 \mu \mathrm{M}, \mathrm{IC}_{50}=96.6 \pm 14.8 \mu \mathrm{M}$, 
respectively for 77-80). Unexpectedly, complexes $\mathbf{7 7 ,} \mathbf{7 9}$, and 80 were found to be completely ineffective against HeLa and HepG2 cells, and complexes $\mathbf{7 9}$ and $\mathbf{8 0}$ were found to not be cytotoxic to MG-63 cells. ${ }^{141}$ Further studies in BEL-7402 cells showed that the complexes induced apoptosis through a ROS-mediated mitochondrial dysfunction pathway, which was accompanied by regulation of the expression of $\mathrm{Bcl}-2$ family proteins. ${ }^{141}$ Fluorescence microscopy studies demonstrated that complexes entered the cells and accumulated in a region around the nucleus.

Almost the same finding was concurrently discovered by Liu and coworkers on two different complexes. $^{142}$ Indeed, $\left.\mathrm{Ru}(\mathrm{dmb})_{2}(\mathrm{NMIP})\right]\left(\mathrm{ClO}_{4}\right)_{2} \quad(\mathbf{8 1})$ and $\left.\mathrm{Ru}(\text { phen })_{2}(\mathrm{NMIP})\right]\left(\mathrm{ClO}_{4}\right)_{2}$ shown in Figure 18 were tested as chemotherapeutic agents against six different cancer cell lines, namely A549, BEL-7402, HeLa, PC-12, SGC-7901 and SiHa. ${ }^{142}$ The complexes were found to have a moderate cytotoxicity against BEL-7402 cells with $\mathrm{IC}_{50}$ values of $53.9 \pm 3.4 \mu \mathrm{M}$ and $39.3 \pm 2.1 \mu \mathrm{M}$, respectively for $\mathbf{8 1}$ and $\mathbf{8 2}$. Unfortunately, these complexes were found to be less active than cisplatin under the same conditions $\left(I C_{50}=10.8 \pm 1.3 \mu \mathrm{M}\right){ }^{142}$ Moreover, complex $\mathbf{8 1}$ had no cytotoxicity toward A549, HeLa, SGC7901 and SiHa cells, and complex 82 was inactive against PC-12, SGC-7901 and SiHa cells. Interestingly, the mechanism of action was investigated also in this case; the authors suggested that the complexes induced apoptosis in BEL-7402 cells through a ROSmediated mitochondrial dysfunction pathway. ${ }^{142}$ Meanwhile, four other Ru(II) polypyridyl complexes (Figure 19) were found to induce apoptosis of HepG2 cells through ROS-mediated

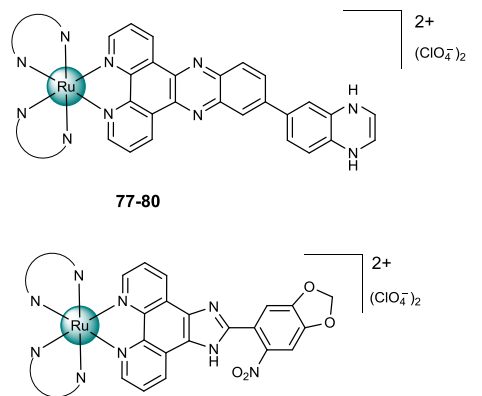

81,82

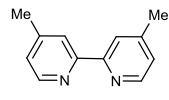

77, 81: dmb
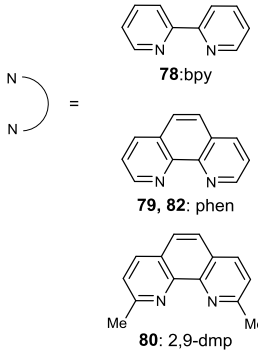

Fig. 18. Structures of $\left.\mathrm{Ru}(\mathrm{dmb})_{2}(\mathrm{DQTT})\right]\left(\mathrm{ClO}_{4}\right)_{2}$ (77), $\left.\mathrm{Ru}(\mathrm{bpy})_{2}(\mathrm{DQTT})\right]\left(\mathrm{ClO}_{4}\right)_{2}$ (78), $\left.\mathrm{Ru}(\text { phen })_{2}(\mathrm{DQTT})\right]\left(\mathrm{ClO}_{4}\right)_{2} \quad$ (79), $\left[\mathrm{Ru}(2,9-\mathrm{dmp})_{2}(\mathrm{DQTT})\right]\left(\mathrm{ClO}_{4}\right)_{2} \quad$ (80), $\left.\mathrm{Ru}(\mathrm{dmb})_{2}(\mathrm{NMIP})\right]\left(\mathrm{ClO}_{4}\right)_{2}(\mathbf{8 1})$ and $\left.\mathrm{Ru}(\text { phen })_{2}(\mathrm{NMIP})\right]\left(\mathrm{ClO}_{4}\right)_{2}(\mathbf{8 2})$. mitochondrial dysfunction pathway. ${ }^{143}$ Zeng and co-workers examined four complexes containing the dhbn ligand, namely
$\left[\mathrm{Ru}(\mathrm{N}-\mathrm{N})_{2}(\mathrm{dhbn})\right]\left(\mathrm{ClO}_{4}\right)_{2}$ where $\mathrm{N}-\mathrm{N}=\mathrm{dmb}(83) ;$ bpy (84); phen (85); 2,9-dmp (86). The cytotoxicity of these complexes was then tested against HepG-2, HeLa, MG-63, and A549. ${ }^{143}$ In all cases, cytotoxic activity induced by the complexes was found to be lower than the control (cisplatin) under the same experimental conditions. Further experiments demonstrated that the complexes could induce apoptosis in Hep-G-2 cells by the activation of the ROS mediated mitochondrial dysfunctional pathway. ${ }^{143}$ Cellular uptake and localization studies showed the ability of the complexes to enter the cells and to accumulate in the nucleus. No clear trend was found to directly correlate the planarity of the ancillary ligands and the cytotoxicity, suggesting that the latter is influenced by other factors. $^{143}$

To find more effective anticancer reagents and obtain more insights into the anticancer activity of Ru(II) polypyridyl complexes, Wan and co-workers between 2016 and 2017 proposed three new dppz-like ligands, namely bddp, PTTP and FTTP. ${ }^{[144-146]}$ In the first place they investigated complexes $\left[\mathrm{Ru}(\mathrm{N}-\mathrm{N})_{2}(\mathrm{bddp})\right]\left(\mathrm{ClO}_{4}\right)_{2} \quad 87-90(\mathrm{~N}-\mathrm{N}=\mathrm{dmb}$ (87), bpy (88), phen (89) and 2,9-dmp (90)) shown in Figure 20. The cytotoxicity in vitro was evaluated against BEL-7402, A549, HeLa and MG-63 cell lines. ${ }^{144}$ Complexes $\mathbf{8 7 - 9 0}$ were found to be highly cytotoxic against all the cell line tested $\left(\mathrm{IC}_{50}\right.$ between $5.3 \pm 0.6 \mu \mathrm{M}$ and $15.7 \pm 3.6 \mu \mathrm{M}$ ) while the ligand itself was completely noncytotoxic. Fluorescent microscopy studies revealed that complexes 87-90 can be taken up by A549 cells and accumulate in the nucleus. $^{144}$ Moreover, they induce apoptosis in the cell line mentioned above through ROS-mediated mitochondrial dysfunctional pathway accompanied by the regulation of the expression of Bcl-2 family proteins. ${ }^{144}$

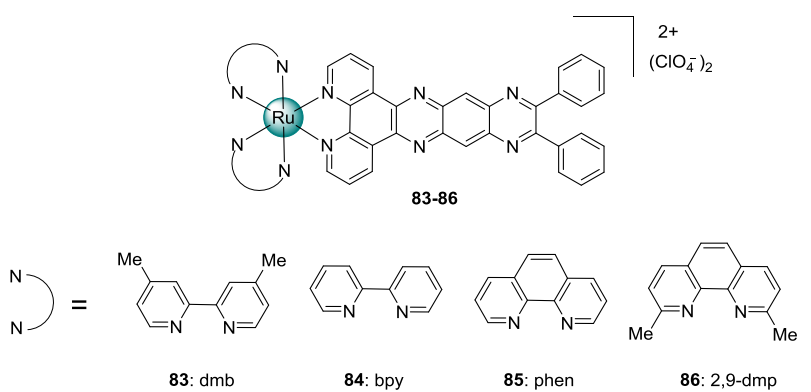

Fig. 19. Structures of $\left[\mathrm{Ru}(\mathrm{N}-\mathrm{N})_{2}(\mathrm{dhbn})\right]\left(\mathrm{ClO}_{4}\right)_{2}(83-86)$.

Afterwards, the same scientists investigated complexes 91-94 shown in Figure 20 carrying PTTP and FTTP ligands and bpy and phen as ancillary ligands.$^{145}$ The in vitro cytotoxicity of these complexes was tested against BEL-7402, HeLa, A549, HepG2 and 
HOS cancer cells. Complex 92 exhibited the highest cytotoxic activity against BEL-7402 and A549 cells, while complexes $\mathbf{9 3}$ and $\mathbf{9 4}$ were found to be more effective against HOS and HepG2 cells, respectively. ${ }^{145}$ As previously discussed, these researchers also observed that larger hydrophobicity led to higher cytotoxicity. Experimental data, in fact, demonstrated that the more lipophilic ancillary ligand such as phen (contained in complexes 92, 94) confers relatively higher cytotoxic activity when compared with complexes containing bpy (more hydrophilic) as ancillary ligands. ${ }^{145}$ This trend was true for all the selected cell lines with the exception of the HOS cell line. ${ }^{145}$ Complexes $\mathbf{9 1 ,} 92$ and $\mathbf{9 4}$ showed higher cytotoxicity than cisplatin against HepG2 cells $\left(\mathrm{IC}_{50}=10.4 \pm 1.2 \mu \mathrm{M}\right.$ $\mathrm{IC}_{50}=9.3 \pm 0.6 \mu \mathrm{M}, \mathrm{IC}_{50}=5.6 \pm 1.2 \mu \mathrm{M}, \mathrm{IC}_{50}=20.3 \pm 2.2 \mu \mathrm{M}$, for $\mathbf{9 1}$

92, 94 and cisplatin respectively). Wan and co-workers suggested that the examined complexes (91-94) induced apoptosis of HepG2 cells through ROS-mediated mitochondrial dysfunction pathway and could regulate the expression of $\mathrm{Bcl}-2$ family proteins. ${ }^{145}$ One year later, the same scientists investigated complexes 95-100 carrying more lipophilic ancillary ligands such as $\mathrm{dmb}, 2,9-\mathrm{dmp}$ and $t$ tbpy. ${ }^{146}$ The cytotoxicity of these complexes was tested against the same cell lines used in the previous study and mentioned above with the addition of the non-cancerous LO2 cell lines. From the $\mathrm{IC}_{50}$ values, it is possible to observe that complexes with the same ancillary ligands are in general more toxic when they carry PTTP ligand instead of FTTP. ${ }^{146}$ In more detail, complex 96 was found to be more active than cisplatin against HeLa, BEL-7402 and HepG-2 with $\mathrm{IC}_{50}$ values going from $4.1 \pm 0.3 \mu \mathrm{M}$ to $2.0 \pm 0.2 \mu \mathrm{M}$. Complex 97 exerted its highest activity against BEL-7402 cells with $\mathrm{IC}_{50}=$ $1.5 \pm 0.1 \mu \mathrm{M}$ while complex 99 was more active against A549 and HOS cell lines. ${ }^{146}$ On the other hand, complex 100 was moderately active against all the cell line tested with $\mathrm{IC}_{50}$ values in the range from $12.8 \pm 0.4 \mu \mathrm{M}$ to $3.2 \pm 0.1 \mu \mathrm{M}$. Unfortunately, all the complexes were not highly selective in the expression of their toxicity since they were found to be also very toxic against healthy LO2 cells. ${ }^{146}$ This work confirmed that by increasing the lipophilicity of the complex, the cytotoxicity of the complex increases. Apoptosis was found to be induced by the activation of a ROS-mediated mitochondrial dysfunction pathway accompanied by the regulation of Bcl-2 family proteins. ${ }^{146}$
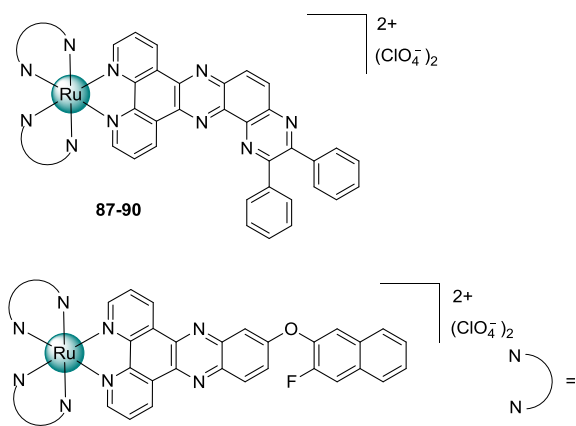

91, 92, 98-100

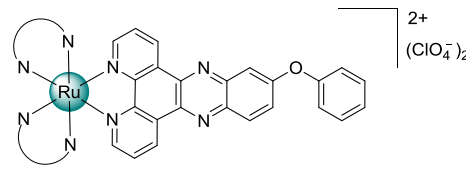

93-97

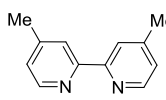

87, 95, 98: dmb

88, 91, 93: bpy

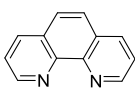

89, 92, 94: phen

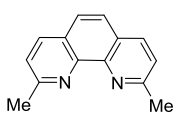

90, 96, 99: 2,9-dmp

t-Bu

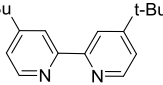

97, 100: ttbpy

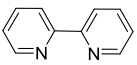

Fig. 20. Structures of $\left[\mathrm{Ru}(\mathrm{dmb})_{2}(\mathrm{bddp})\right]\left(\mathrm{ClO}_{4}\right)_{2}(87),\left[\mathrm{Ru}(\mathrm{bpy})_{2}(\mathrm{bddp})\right]\left(\mathrm{ClO}_{4}\right)_{2}$ (88), $\left[\mathrm{Ru}(\text { phen })_{2}(\mathrm{bddp})\right]\left(\mathrm{ClO}_{4}\right)_{2} \quad(89),\left[\mathrm{Ru}(2,9-\mathrm{dmp})_{2}(\mathrm{bddp})\right]\left(\mathrm{ClO}_{4}\right)_{2} \quad$ (90), $\left[\mathrm{Ru}(\mathrm{bpy})_{2}(\mathrm{FTTP})\right]\left(\mathrm{ClO}_{4}\right)_{2} \quad(\mathbf{9 1}), \quad\left[\mathrm{Ru}(\text { phen })_{2}(\mathrm{FTTP})\right]\left(\mathrm{ClO}_{4}\right)_{2} \quad$ (92) $\left[\mathrm{Ru}(\mathrm{bpy})_{2}(\mathrm{PTTP})\right]\left(\mathrm{ClO}_{4}\right)_{2} \quad(\mathbf{9 3}), \quad\left[\mathrm{Ru}(\text { phen })_{2}(\mathrm{PTTP})\right]\left(\mathrm{ClO}_{4}\right)_{2} \quad(\mathbf{9 4})$ $\left[\mathrm{Ru}(\mathrm{dmb})_{2}(\mathrm{PTTP})\right]\left(\mathrm{ClO}_{4}\right)_{2} \quad(95), \quad\left[\mathrm{Ru}(2,9-\mathrm{dmp})_{2}(\mathrm{PTTP})\right]\left(\mathrm{ClO}_{4}\right)_{2} \quad$ (96) $\left[\mathrm{Ru}(\mathrm{ttbpy})_{2}(\mathrm{PTTP})\right]\left(\mathrm{ClO}_{4}\right)_{2} \quad(97), \quad\left[\mathrm{Ru}(\mathrm{dmb})_{2}(\mathrm{FTTP})\right]\left(\mathrm{ClO}_{4}\right)_{2} \quad$ (98), $\quad[\mathrm{Ru}(2,9-$ $\left.\mathrm{dmp})_{2}(\mathrm{FTTP})\right]\left(\mathrm{ClO}_{4}\right)_{2}$ (99), [Ru(ttbpy $\left.)_{2}(\mathrm{FTTP})\right]\left(\mathrm{ClO}_{4}\right)_{2}(\mathbf{1 0 0})$.

In 2014, Luo and co-workers suggested a completely new mechanism of action for their Ru(II) polypyridyl complexes by proposing mitochondrial thioredoxin reductase ( $\operatorname{Tr} x \mathrm{R})$ as a target for their $\mathrm{Ru}(\mathrm{II})$ complexes. $^{147}$ The thioredoxin system, which is composed of thioredoxin (Trx), TrxR and NADPH, has been intensively considered as an interesting target in anticancer research over the last five years. It has a key role in regulating redox balance and intracellular signalling pathways. TrxR is a homodimeric selenoenzyme characterised by a broad substrate specificity. Moreover, the propensity of the active site selenolate group to react with "soft" metal ions, makes it a good target for metal-based drugs. So far, only complexes with labile ligands have been investigated (i.e. cisplatin, gold complexes, Ru(II)-arene compounds, $\mathrm{Ru}(\mathrm{II}) \mathrm{N}$-heterocyclic carbene complexes) because the inhibition of such enzyme is believed to be due to the covalent binding between the metal and the selenium. ${ }^{[148-152]}$ In this specific article, $\mathrm{Ru}(\mathrm{II})$ polypyridyl complexes were considered, for the first time, as inhibitors of mitochondrial TrxR. Inter alia, $\left[\mathrm{Ru}(\mathrm{bpy})_{3}\right]\left(\mathrm{ClO}_{4}\right)_{2}(\mathbf{1 0 1})$, $\left[\mathrm{Ru}(\text { phen })_{3}\right]\left(\mathrm{ClO}_{4}\right)_{2}(102),\left[\mathrm{Ru}(\mathrm{ip})_{3}\right]\left(\mathrm{ClO}_{4}\right)_{2} \quad(103),\left[\mathrm{Ru}(\mathrm{pip})_{3}\right]\left(\mathrm{ClO}_{4}\right)_{2}$ (104) (Figure 21) were tested against various cancer cell lines, namely, A375, MCF-7, PC-12, HepG-2 and A549 cells in order to evaluate their in vitro cytotoxicity. ${ }^{147}$ Afterwards, the interaction of 
the complexes with TrxR and their lipophilicity were investigated. Experimental data showed that increasing the lipophilicity led to an increased cytotoxicity. On the other hand, the most lipophilic compound (104) had the greatest TrxR inhibitory potency. ${ }^{147}$ The mechanism of action suggested by these researchers considered TrxR as the first target of the complex 104. In order to obtain more insights about the possible interactions, these scientists used mass spectrometry. In particular, they employed the selenocysteinecontaining model peptide Ala-Gly-Sec-Val-Gly-Ala-Gly-Leu-Ile-Lys (AGUVGAGLIK) for the study of the possible interaction with the active site of TrxR. ${ }^{153}$ After $12 \mathrm{~h}$ of treatment with the complex 104, the molecular peak of the selenopeptide completely vanished. This was accompanied by the appearance of a peak with the mass corresponding to the fragment (H-UVGA-OH) attached to $104 .{ }^{147}$ This data made the scientists suggest that the Ru(II) polypyridyl complexes might form a covalent adduct with the selenol of the selenocysteine, thus affecting the TrxR activity. To confirm this hypothesis, a photophysical study of complex 104 was carried out in the presence of the selenopeptide under physiological conditions (at $37^{\circ} \mathrm{C}$ in PBS buffer). ${ }^{147}$ The results showed a concomitant disappearance of the absorption band of complex 104 and the rise of a new one centred at $497 \mathrm{~nm}$. In addition, no luminescence was found when 104 was incubated with the selenopeptide. ${ }^{147}$ The authors could also demonstrate that the inhibition of TrxR then promoted the generation and accumulation of ROS, leading to cell apoptosis through the activation of mitochondrial pathway. ${ }^{147}$ However, since the complex is substitutionally inert, coordination of the metal seems impossible. Unfortunately, no further information is available about the suggested covalent adduct which must occu between the ligand of complex 104 and the selenol.

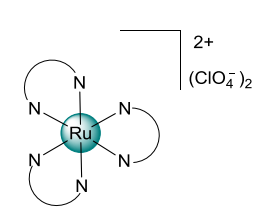

101-104

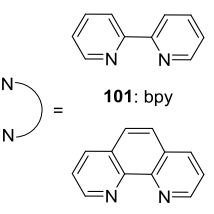

102: phen

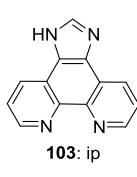

03: ip

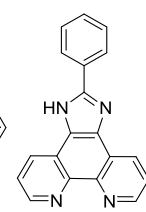

104: pip
Fig. 21. Structures of $\left[\mathrm{Ru}(\mathrm{bpy})_{3}\right]\left(\mathrm{ClO}_{4}\right)_{2}$ (101), $\left[\mathrm{Ru}(\text { phen })_{3}\right]\left(\mathrm{ClO}_{4}\right)_{2} \quad$ (102), $\left[\mathrm{Ru}(\mathrm{ip})_{3}\right]\left(\mathrm{ClO}_{4}\right)_{2}(\mathbf{1 0 3}),\left[\mathrm{Ru}(\mathrm{pip})_{3}\right]\left(\mathrm{ClO}_{4}\right)_{2}(\mathbf{1 0 4})$.

\subsection{Short conclusions}

Overall, as shown with the many examples presented above, the general trend observed for monomeric $\mathrm{Ru}(\mathrm{II})$ polypyridyl complexes is that the more lipophilic complexes are generally more cytotoxic due to a greater cellular uptake. However, it is extremely difficult to rationalise all results reported to date and to allow for a general trend of their biological activity since targets for these complexes can be different. It is also interesting to note that the cellular localisation of $\mathrm{Ru}(\mathrm{II})$ polypyridyl complexes is difficult to predict since many parameters (i.e. size, charge, presence of hydrogen bonds, structural features, etc.) are playing a role.

\section{Dinuclear Ru(II) polypyridyl complexes}

Below, we review the cytotoxic dinuclear $\mathrm{Ru}(\mathrm{II})$ polypyridyl complexes reported to date by considering their biological targets.

\subsection{Dinuclear Ru(II) complexes targeting DNA}

The interest towards the cytotoxicity of dinuclear $\mathrm{Ru}(\mathrm{II})$ polypyridyl complexes targeting DNA arose around $2007 .{ }^{154}$ At that time, Hotze and co-workers studied a triple-stranded ruthenium cylinder (showed in Figure 22) and demonstrated that such a complex binds and coils DNA. ${ }^{154}$ Interestingly the cytotoxicity was found to be only 2-5 times lower than cisplatin $\left(\mathrm{IC}_{50}=22 \mu \mathrm{M}\right.$ and $\mathrm{IC}_{50}=4.9 \mu \mathrm{M}$ for the dimeric complex and cisplatin, respectively against HBL100 cells). One year later, they investigated a class of compounds of the type $\left[\mathrm{Ru}_{2}(L L)_{4} L^{1}\right]\left(\mathrm{PF}_{6}\right)_{4}$ where $\mathrm{LL}=$ bpy or phen and $\mathrm{L}^{1}=\mathrm{C}_{25} \mathrm{H}_{20} \mathrm{~N}_{4}$ a bis(pyridylimine) ligand containing a diphenylmethane spacer (105 in Figure 23 is an example of such structures). ${ }^{155}$ The cytotoxicity of these complexes was tested against HBL100 and SKOV-3 cell lines.

Figure 22. Crystal Structure of $\left[\mathrm{Ru}_{2} \mathrm{~L}_{3}\right]^{4+}$ cation. ${ }^{154}$ Ru green, $\mathrm{N}$ violet, $\mathrm{C}$ grey.

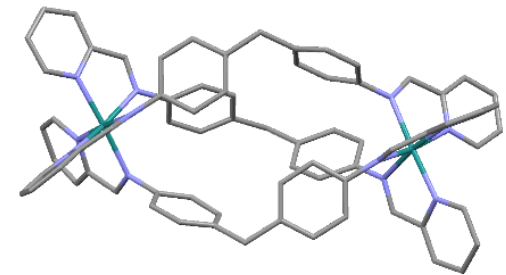

Hydrogen atoms, anions $\left(4 \mathrm{xF}_{6}{ }^{-}\right)$, and co-crystallized solvent molecules $\left(\mathrm{H}_{2} \mathrm{O}\right.$ and benzene) are omitted for clarity. 
Unfortunately, it was found that they hardly inhibited cell proliferation. The slight activity combined with the low solubility of the compound avoided the determination of absolute $\mathrm{IC}_{50}$ values. ${ }^{155}$ In 2007, MacDonnell and co-workers found out that the ruthenium dimer $\left[(\text { phen })_{2} R u(\right.$ tatpp $\left.) R u(\text { phen })_{2}\right](C l)_{4}(106$ Figure 24$)$ could induce DNA cleavage in vitro and that this cleavage was enhanced under anaerobic conditions. ${ }^{156}$ Complex 106 is known to intercalate and to bind DNA tightly, but as already mentioned above, this is not a sufficient condition to induce DNA damage. ${ }^{[74,156]}$ Experimental data showed that DNA damage was caused by in situ reduction of complex 106 with glutathione (GSH). Moreover, exposure to air, even in a large excess of reductive agent, attenuated the cleavage activity. ${ }^{156}$ The active species was found to be the doubly protonated complex $\mathbf{H}_{\mathbf{2}} \mathbf{1 0 6}$ shown in Figure 24. As previously suggested by Yamaguchi and co-workers, DNA cleavage can occur via oxygen-dependent and independent pathways. ${ }^{[157,158]}$ On these bases, the authors suggested that the $\mathbf{H}_{\mathbf{2}} \mathbf{1 0 6}$ compound was directly related to the production of radical carbon species responsible for DNA cleavage. ${ }^{156}$ This latter statement was demonstrated by the attenuation of DNA cleavage in the presence of TEMPO (carbon radical scavenger) and not in the presence of DMSO (ROS scavenger). ${ }^{156}$ This was the first example reported in the literature of a metal complex with potentiated DNA cleavage activity under hypoxia conditions. This interesting finding suggested the possible application of such complexes as a target for tumour cells, which are often characterised by a low-oxygen environment. ${ }^{159}$

With these results in hand, in 2013, MacDonnell and co-workers demonstrated, for the first time, the in vivo anticancer activity of such Ru(II) polypyridyl complexes. ${ }^{160}$ These researchers discovered that the enhanced biological activity of their complexes was associated with the tatpp ligand. From this study, in fact, 106 in

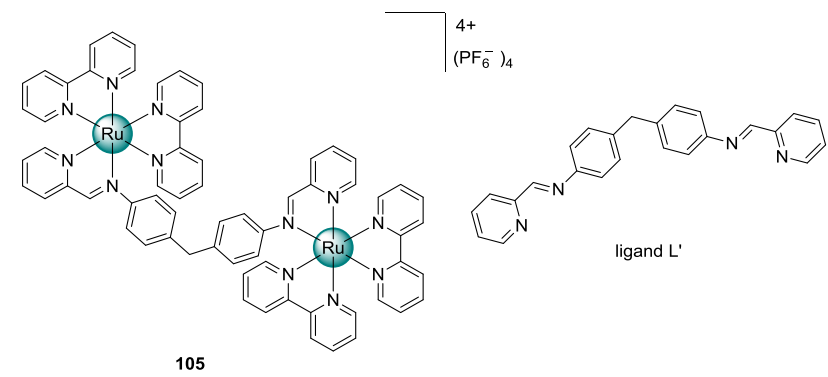

Figure 23. Structures of $\left[R u(b p y)_{2} L^{1}\right]\left(\mathrm{PF}_{6}\right)_{4}(105)$ and ligand $L^{\prime}$.

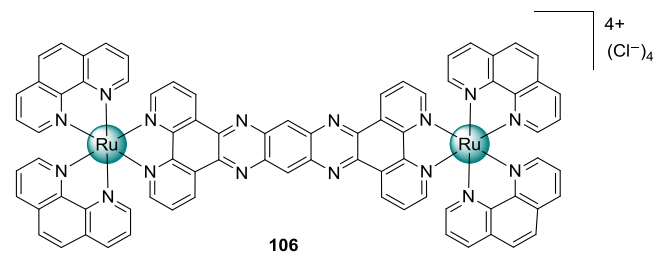

106

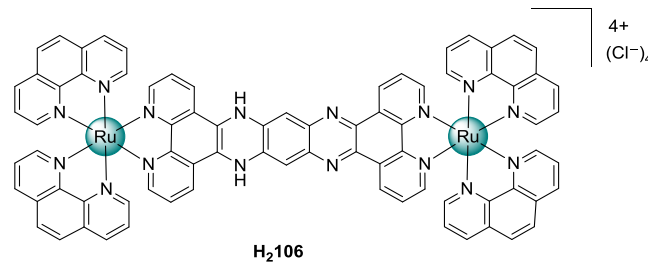

Fig. 24. Structures of $\left[(\text { phen })_{2} \mathrm{Ru}(\right.$ tatpp $\left.) R u(\text { phen })_{2}\right](\mathrm{Cl})_{4}(\mathbf{1 0 6})$ and of its reduced form $\mathrm{H}_{2} 106$.

Figure 24 and 107 in Figure 25 (complexes containing the tatpp ligand) were found to be more efficient and selective for inducing apoptosis in cultured NSCLC cell lines when compared to other complexes containing different ligands (such as $\left[R u(\text { phen })_{2}(\mathrm{dppz})\right](\mathrm{Cl})_{2}(\mathbf{1 0 8}), \quad\left[\mathrm{Ru} \quad(\text { phen })_{2}(\mathrm{tpphz})\right](\mathrm{Cl})_{2} \quad(\mathbf{1 0 9}), \quad[\mathrm{Ru}$ $\left.(\text { phen })_{3}\right](\mathrm{Cl})_{2}(\mathbf{1 1 0}),\left[(\text { phen })_{2} \mathrm{Ru}(\text { tpphz)Ru(phen })_{2}\right](\mathrm{Cl})_{4}(\mathbf{1 1 1})$, shown in Figure 25). ${ }^{160}$ The authors showed a significant tumour growth repression and a doubling of the survival time of mice with $\mathrm{H} 358$ human lung cancer xenograft. MacDonnell and co-workers hypothesised the likely mechanism of DNA damage: the tatpp carbon radical in the reduced species abstracts a $\mathrm{H}$-atom from the deoxyribose unit. ${ }^{160}$ The concentration of the key intermediate is
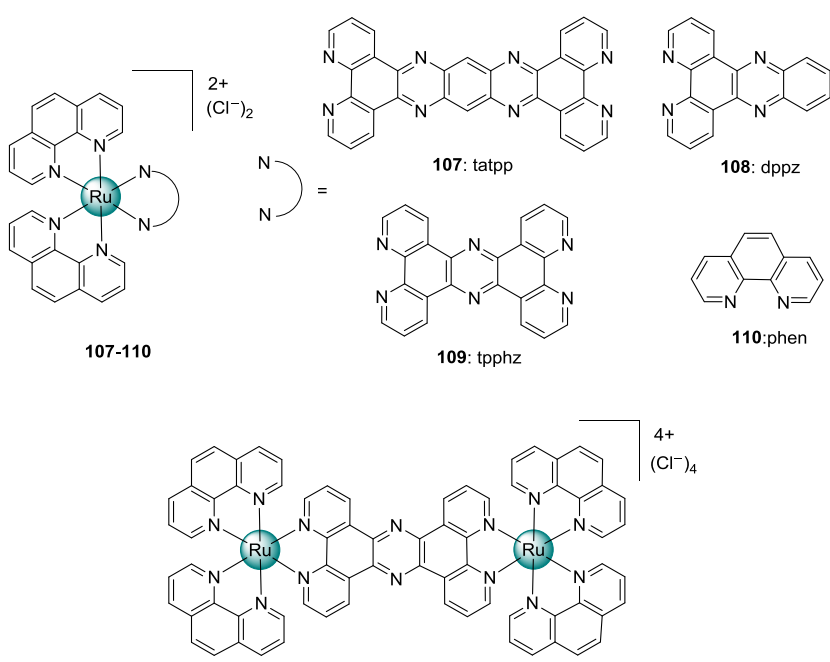

111

Fig. 25. Structures of $\left[\mathrm{Ru}(\text { phen })_{2}(\operatorname{tatpp})\right](\mathrm{Cl})_{2}(\mathbf{1 0 7}),\left[\mathrm{Ru}(\mathrm{phen})_{2}(\mathrm{dppz})\right](\mathrm{Cl})_{2}$

(108), $\left[\operatorname{Ru}(\text { phen })_{2}(\right.$ tpphz $\left.)\right](C l)_{2} \quad(\mathbf{1 0 9}), \quad\left[\operatorname{Ru}(\text { phen })_{3}\right](\mathrm{Cl})_{2} \quad(\mathbf{1 1 0})$, $\left[(\text { phen })_{2} \mathrm{Ru}(\right.$ tpphz $\left.) \mathrm{Ru}(\text { phen })_{2}\right](\mathrm{Cl})_{4}$ (111). ligand. ${ }^{161}$ 
dependent on the $\mathrm{O}_{2}$ and reducing agent concentrations. Moreover, since tatpp can be reduced again, the concentration of the key carbon radical species is controlled by the $\mathrm{O}_{2}$ and reducing agent concentrations. Interestingly, complexes 106 and 107 showed significant selectivity against malignant cells. This observation could be explained by the differences in transport mechanisms. ${ }^{160}$ Complexes 108, 110, 111 were generally shown to enter cells via passive diffusion, ${ }^{[162,163]}$ while it seems reasonable to assume that complexes 106 and 107 enter cells via active transport as already demonstrated for $\mathrm{Ru}(\mathrm{II})$ polypyridyl complexes containing the tpphz In order to obtain more insights into this class of metal complexes, MacDonnell and co-workers investigated a number of derivatives in which the terminal 1,10-phenantroline ligands were replaced with more lipophilic ligands, such as DIP or tmphen. ${ }^{164}$ In this work, they carried out a structure-activity relationship study examining the cytotoxicity of $\mathrm{Ru}(\mathrm{II})$ polypyridyl complexes against three malignant (MCF7, CCL228, and H358) and one non-malignant (MCF10) human cultured cell lines. All the Ru(II) complexes carrying non-redox active ligands were found to be slightly active against the cell lines tested. ${ }^{164}$ Complexes $\mathbf{1 1 2}$ and $\mathbf{1 1 3}$ (shown in Figure 26) are the most lipophilic complexes containing the tatpp ligand examined in this work and showed consistent cytotoxicity against malignant cell lines $\left(\mathrm{IC}_{50} \approx 10 \mu \mathrm{M}\right) .{ }^{164}$ At the same time, they were also well-tolerated by non-

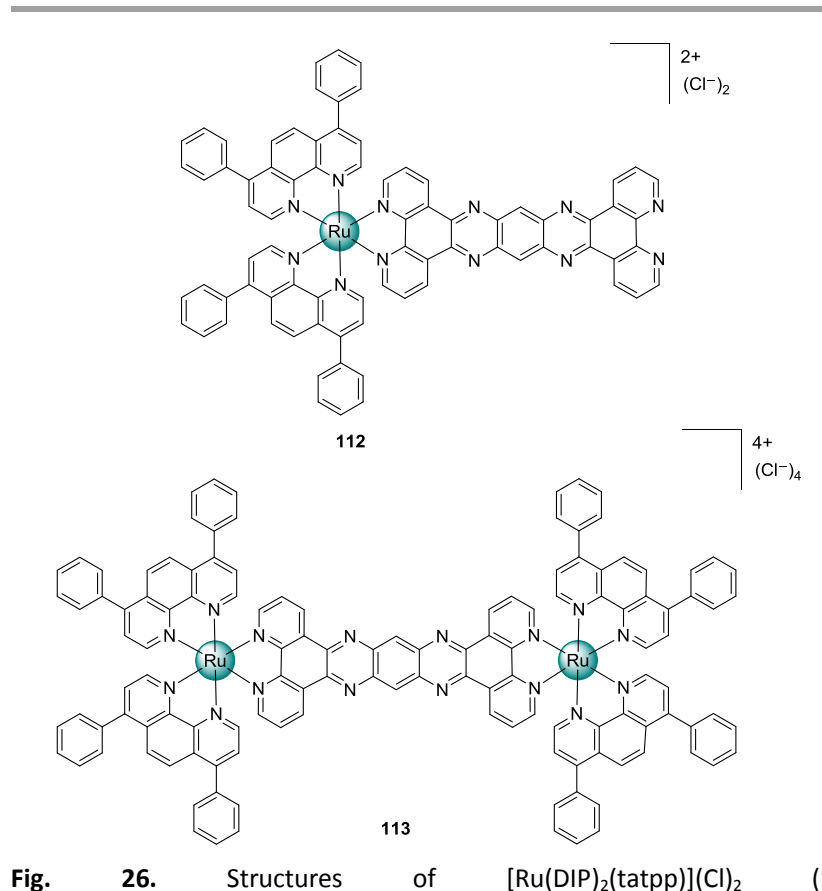

$\left[(\mathrm{DIP})_{2} \mathrm{Ru}(\right.$ tatpp $\left.) \mathrm{Ru}(\mathrm{DIP})_{2}\right](\mathrm{Cl})_{4}(\mathbf{1 1 3})$ malignant MFC10 cells. This data is in complete agreement with the trend found during the in vitro AChE inhibition studies. ${ }^{164}$ It is clear, that the lipophilicity is inversely proportional to the AChE inhibition ability. Moreover, in vivo toxicity studies suggested that the tatpp ligand might be responsible for lowering the observed toxicity. ${ }^{164}$ In 2017, MacDonnell and co-workers proposed a mechanistic model to explain the dependency of the DNA cleavage on oxygen concentration. $^{165}$ In more detail, they performed cell-free experiments, whose data supported the mechanistic pathway shown in Figure 27 . The mechanism exhibits a multistep pathway by which Ru(II) polypyridyl complexes 106 and 107 undergo a redoxcycling mediated by the $[\mathrm{GSH}]$ and $\left[\mathrm{O}_{2}\right]$ which activate $\mathrm{O}_{2}$ to produce superoxide and hydrogen peroxide. ${ }^{165} \mathrm{H}_{2} \mathrm{O}_{2}$ has a central role since it is an indispensable intermediate in the cleavage mechanism. ${ }^{[166,167]}$ Moreover, it can be directly produced in a single step via a 2-electron, 2-proton transfer to $\mathrm{O}_{2}$ by $\mathbf{H}_{2} \mathbf{1 0 6}$ (or $\mathrm{H}_{2} 107$ ). Since, the steady state concentration of $\mathbf{H}_{2} \mathbf{1 0 6}$ increases under hypoxic conditions, $\mathrm{H}_{2} \mathrm{O}_{2}$ is

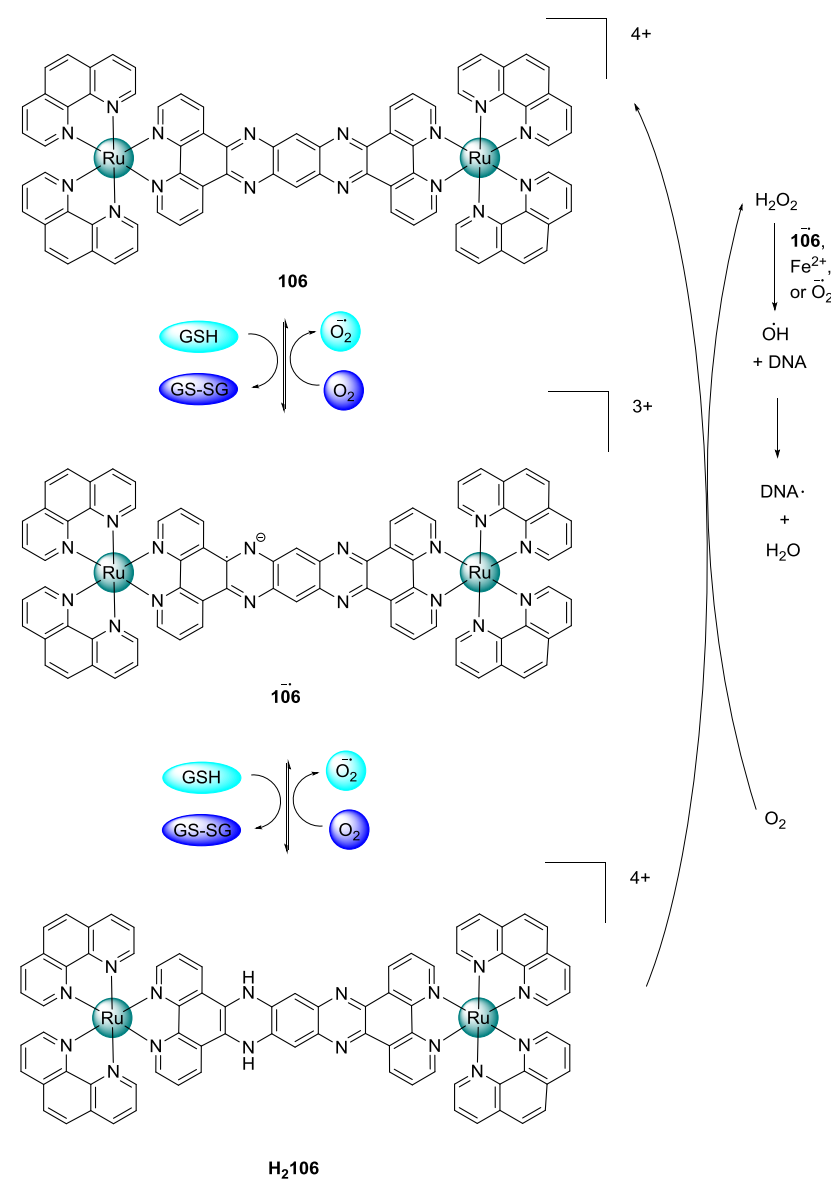

Fig. 27. Redox cycling pathway for $106 .^{165}$ 
produced more efficiently and DNA cleavage is enhanced. ${ }^{165}$ Furthermore, the in vitro cytotoxicity of 106 and 107 was examined against H358, HCC2998, HOP-62, Hs766t cell lines under normoxia $\left(18 \% \mathrm{O}_{2}\right)$ and hypoxia $\left(1.1 \% \mathrm{O}_{2}\right)$. Unlike many $\mathrm{O}_{2}$ activating drugs which are less effective under hypoxic conditions, 106 showed no differences in cytotoxicity going from normoxia to hypoxia. ${ }^{165}$ Complex $\mathbf{1 0 7}$ is two-times more cytotoxic under hypoxic conditions in HOP-62, Hs766t when compared to normoxia. From the results discussed above, it seems that the role of ruthenium is mostly structural, so it would be very interesting to investigate analogues of these complexes containing different metals (e.g. osmium).

\subsection{Dinuclear $\mathrm{Ru}(\mathrm{II})$ complexes targeting mitochondria}

Between 2010 and 2011 Keane, Collins and co-workers investigated a class of dinuclear Ru(II) polypyridyl complexes where the metals are linked by a flexible bridge $\left(\Delta \Delta / \wedge \Lambda-\left[\left\{\mathrm{Ru}(\text { phen })_{2}\right\}_{2}\left\{\mu-\mathrm{bb}_{n}\right\}\right](\mathrm{Cl})_{4} 114\right.$ in Figure 28). ${ }^{[168,169]}$ They demonstrated that increasing the lipophilicity of the complexes by increasing the length of the alkane chain significantly improved the cytotoxic properties. ${ }^{168}$ The cytotoxicity of this family of $\mathrm{Ru}(\mathrm{II})$ complexes was analysed in the L1210 cell line. It was found that $\Delta \Delta$ isomers were more active than their counterpart $\Lambda$. This observation is in agreement with that found for other dimeric complexes. ${ }^{164}$ The predominant site of accumulation of $\mathbf{1 1 4}$ are mitochondria and the cytotoxicity is positively direct correlated

with cellular accumulation. Changes in cell morphology were observed after treatment with the series of complexes, indicating the induction of apoptosis. ${ }^{168}$ Subsequently, a time-course experiment using annexin V450 showed that the level of apoptosis induced by $\Delta \Delta-\mathrm{Rubb}_{16}$ in the $\mathrm{L} 1210$ cell line is time dependent. ${ }^{169}$ Flow cytometric studies demonstrated that $\Delta \Delta-\mathrm{Rubb}_{16}$ was taken up by both $L 1210$ cells and primary B cells to different degrees, despite the close relationship of the two cell types. In more detail, a greater uptake by L1210 was recorded, suggesting a selective accumulation

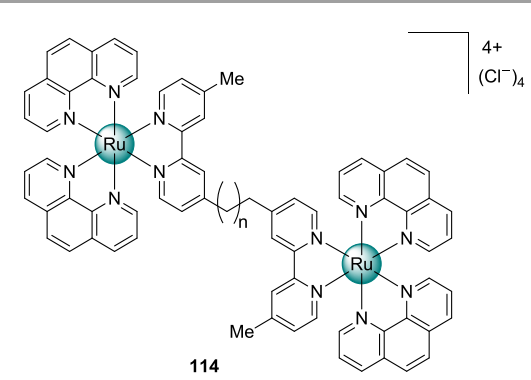

Fig. 28. Structure of $\left[\left\{\mathrm{Ru}(\text { phen })_{2}\right\}_{2}\left\{\mu-\mathrm{bb} \mathrm{b}_{n}\right\}\right](\mathrm{Cl})_{4}(\mathbf{1 1 4})$. in cancer cells. ${ }^{169}$ Further studies revealed that the introduction of polyether or polyamine in the linking chains lowered the cytotoxicity, while the trinuclear and tetranuclear species exerted higher activity when compared with their dinuclear analogues. ${ }^{170}$ Moreover, this class of complexes showed interesting results as potential antimicrobial agents. ${ }^{171}$ Inter alia, they expressed a selective in vitro toxicity against gram positive and gram negative bacteria while they remain non-toxic for eukaryotic cells at concentrations significantly greater than the corresponding MIC value (minimal inhibitory concentration). ${ }^{[171,172]}$ Interestingly, a later study on $\Delta \Delta-\mathrm{Rubb}_{12}$ and its derivatives revealed a high selectivity for nucleus accumulation in BHK, HEK-293 and Hep-G2 cell lines. ${ }^{172}$ These results showed a potential level of cell type selectivity.

\subsection{Dinuclear Ru(II) complexes targeting biological membranes}

In 2013, Gill and co-workers examined other dimeric Ru(II) polypyridyl complexes, namely $\left[\left(\operatorname{Ru}(\mathrm{DIP})_{2}\right)_{2}(\mathrm{tpphz})\right](\mathrm{Cl})_{4}$ and $\left[\left(\mathrm{Ru}(\text { phen })_{2}\right)_{2}(\mathrm{tpphz})\right](\mathrm{Cl})_{4} \quad(\mathbf{1 1 5}$ and $\mathbf{1 1 6}$ in Figure 29, respectively). ${ }^{173}$ They previously reported the cellular uptake properties of the dinuclear $\mathrm{Ru}(\mathrm{II})$ complex $\mathbf{1 1 6}$ demonstrating that this luminescent light switch complex functions as a DNA imaging agent. ${ }^{161}$ On the other hand, the most lipophilic analogue $\mathbf{1 1 5}$ was found to have possible applications as an in cellulo imaging agent targeting mainly lipid-dense endoplasmic reticulum (ER). ${ }^{173}$ Cellular localisation studies showed that the targets of this compound are biological membranes with the major accumulation recorded in the ER. ${ }^{173}$ Eukaryotic cell's secretory, endocytic, and degradative processes involve membrane-enclosed transport carriers to move diverse molecules among membrane-bound compartments. ${ }^{174}$ As a result, membrane-enclosed intracellular structures and organelles

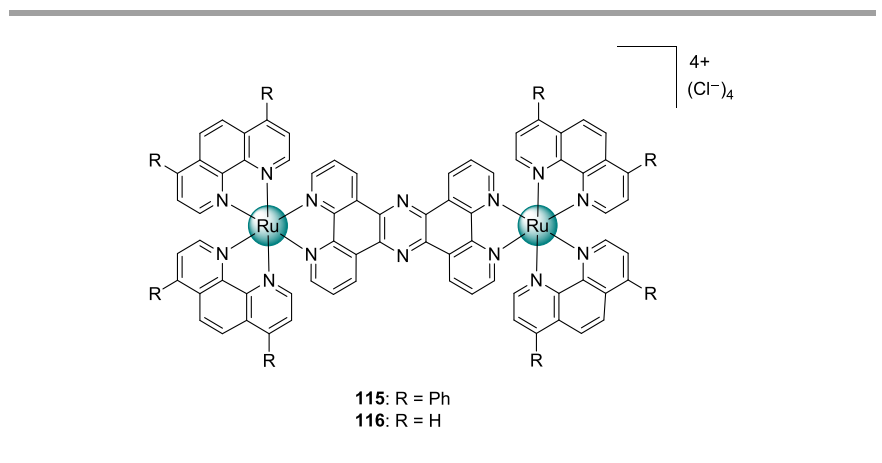

Fig. 29. Structures of $\left[\left(\operatorname{Ru}(\mathrm{DIP})_{2}\right)_{2}(\mathrm{tpphz})\right](\mathrm{Cl})_{4} \quad(\mathbf{1 1 5}) \quad$ and $\left[\left(\mathrm{Ru}(\text { phen })_{2}\right)_{2}(\mathrm{tpphz})\right](\mathrm{Cl})_{4}(\mathbf{1 1 6})$. 
interaction and regulation within eukaryotic cells is of vital relevance within cell biology and medicine. ${ }^{174}$ The in vitro cytotoxicity of the Ru(II) complex was tested towards MCF-7 and HeLa cells and was found to be comparable to cisplatin. Cellular morphology studies suggested necrosis as the main cause of cell death since no evidence of apoptosis was found. ${ }^{173}$ However, future studies are needed to provide more detailed insights about the bioactivity of 115

\subsection{Short conclusions}

Overall, as can be seen with the studies reported to date with dinuclear Ru(II) complexes, the main targets of these compounds are DNA, mitochondria or biological membranes. Among the complexes targeting DNA, dimeric complex 106 showed the greatest potential due to its peculiar properties (i.e. great selectivity and high cytotoxicity under hypoxia). In addition, promising in vivo results were obtained which showed relatively low acute animal toxicity and demonstrable tumour regression in murine tumour models. Other similar complexes were investigated and it is interesting to note that the complexes containing non-redox ligands showed much lower activity, while no clear trend in respect to lipophilicity was found. In fact, the most lipophilic analogue of compound 106, namely 112 showed IC $C_{50}$ between $1.5 \mu \mathrm{M}$ and 100 $\mu \mathrm{M}$ depending on the cell line studied, while complexes 106 and 107 (which are one order of magnitude less lipophilic) were found to be some of the complexes presenting the broadest activity. On the contrary, in the case of all the other dinuclear Ru(II) polypyridyl complexes reported here, the general trend stating that more lipophilic complexes lead to highest cytotoxicity was confirmed.

\section{Conclusions}

Over the years, Ru(II) polypyridyl complexes were shown to have promising bactericidal, bacteriostatic and anti-cancer activity. Unfortunately, not much in vivo data is currently publicly available, rendering it difficult to assess the full potential of this class of compounds. A highlight is undoubtedly the dinuclear complex 106 ([(phen) $\left.\left.)_{2} \mathrm{Ru}(\text { tatpp)Ru(phen })_{2}\right](\mathrm{Cl})_{4}\right)$ discovered by MacDonnell and co-workers. This complex exerts its cytotoxicity, targeting directly DNA with a carbon radical generated by the in situ reduction of a special ligand, namely tatpp. Moreover, in vivo studies suggested that the tatpp ligand might be responsible for a decrease in toxicity.
Very interestingly, complex 106 showed a great selectivity towards cancer cells and its cytotoxicity improves under hypoxia (condition usually found in cancer cells). In our opinion, these properties associated with the promising in vivo data reported make complex 106 the most promising compound presented in this Review. However, further investigations are needed to validate the full potential of this compound as well as the correlation between the lowered toxicity observed and the AChE inhibition.

Overall, we hope that this Review will be beneficial for scientists aiming to improve the clinical profile of this class of compounds in terms of cytotoxicity and in vivo tolerability. We are extremely impatient to read new developments in this field of research in the near future.

\section{Ligand abbreviation}

2-appt= 2-amino-4-phenylamino-6-(2-pyridyl)-1,3,5-triazine

2,9-dmp = 2,9-dimethyl-1,10-phenanthroline

4,7-dmp = 4,7-dimethyl-1,10-phenanthroline

5 -idip $=2$-indole- $[4,5-f][1,10]$ phenanthroline

7-Br-dppz = 7-bromo-dipyrido[3,2-a:2",3"-c]

addppn $=$ acenaphtheno[1,2-b]-1,4-diazabenzo[i]dipyrido[3,2$\left.a: 2^{\prime}, 3^{\prime} c\right]$ phenazine

adppz = dipyrido[3,2-a:2', $\left.3^{\prime}-c\right]$ phenazin-11-amine

AHPIP = 2-(3-amino-4-hydroxylphenyl)imidazo[4,5-

f][1,10]phenanthroline)

azpy $=2$-phenylazopyridine

$\mathrm{bb}_{n}=1, n$-bis $\left[4\left(4^{\prime}\right.\right.$-methyl-2,2'-bipyridyl $\left.)\right]$-nane $(n=2,5,7,10,12$ or 16)

bddp=benzilo[2,3-b]-1,4-diazabenzo[i]dipyrido[3,2-a:2', $3^{\prime}-$

c]phenazine

bppp $\quad=\quad$ 11-bromo-pyrido[2', $\left.3^{\prime}: 5,6\right]$ pyrazino $[2,3-$

f][1,10]phenanthroline

bpy $=2,2^{\prime}$-bipyridine

bpy-2-nitrolm = 4-[3-(2-nitro-1H-imidazol-1-yl)propyl]

CNPFIP = 2-(5(4-chloro-2-nitrophenyl)furan-2-yl) $-1 \mathrm{H}-$ imidazo[4,5f][1,10]phenanthroline)

$\mathrm{CppH}=2-\left(2^{\prime}-\right.$ pyridyl) pyrimidine-4-carboxylic acid

$\mathrm{Cpp}-\mathrm{NH}-\mathrm{Hex}-\mathrm{COOH}=6-(2-$ pyridin-2-yl)pyrimidine-4-

carboxamido)hexanoic acid

dhbn $=$ 12,13-diphenylpyrazino[2,3-i]dipyrido[3,2-a:2',3'-

c]phenazine

DIP = 4,7-diphenyl-1,10-phenanthroline 
$\mathrm{dmab}=4,4^{\prime}$-bis(N,N-dimethylamino)-2,2'-bipyridine

$\mathrm{dmb}=4,4^{\prime}$-dimethyl-2,2'-bipyridine

$\mathrm{dmcb}=4,4^{\prime}$-dimethoxycarbonyl-2,2' -bipyridine

dmdppz = 5,8-dimethoxylpyrido[3,2-a:2', $\left.3^{\prime}-c\right]$ phenazine

$\mathrm{dmob}=4,4^{\prime}$-dimethoxy-2,2'-bipyridine

dppz = dipyrido[3,2-a:2',3'-c]phenazine

DQTT = 12-(1,4-dihydroquinoxalin-6-yl)-4,5,9,14-

tetraazabenzo[b]triphenylene, $\mathrm{dmb}=4,4^{\prime}$-dimethyl-2,2'-bipyridine

FTTP = 2-(3-fluoronaphthalen-2- yloxy)-1,4,8,9-tetraazatriphenylene

$\mathrm{H}_{2}$ IIP = 2-(indole-3-yl)-imidazo[4,5-f][1,10]phenanthroline

Hphox $=2-\left(2^{\prime}-\right.$ hydroxyphenyl)oxazoline

ip = imidazole $[4,5-f][1,10]$ phenanthroline,

ipad $\quad=\quad 2$-(anthracene-9,10-dione-2-yl)imidazo[4,5-

f][1,10]phenanthroline)

NHPIP = 2-(3-nitro- 4- hydroxylphenyl)imidazo[4,5-

f] $[1,10]$ phenanthroline)

NMIP = 2'-(2"-nitro-3",4"-methylenedioxyphenyl)imidazo[4',5'-

f] $[1,10]$-phenanthroline

Norharman $=9 \mathrm{H}$-pyrido[3,4-b]indole

PAIDH= 2-Pyridyl-1H-anthra[1,2-d]imidazole-6,11-dione

pddppn: phenantheno[1,2-b]-1,4-diazabenzo[i]dipyrido[3,2-a:2',3'-

c]phenazine

phen $=1,10$ phenantroline

pip = 2-phenylimidazo[4,5-f][1,10]phenanthroline)

psbr $\quad$ 2-(5-bromothiophen-2-yl) imidazo[4,5-

f][1,10]phenanthroline

pscl = 2-(5-chlorothiophen-2-yl)imidazo[4,5-f][1,10]phenanthroline

ptip $=(2-(5-p h e n y l t h i o p h e n-2-y l)-1 \mathrm{H}-\quad$ imidazo[4, 5-f][1,10

phenanthroline

PTTP = 2-phenoxy-1,4,8,9- tetraazatriphenylene

pztp = 3-(pyrazin-2-yl)-[1,2,4]triazino[5,6-f][1,10]phenanthroline

$\mathrm{R}_{2}$ bpy = 5,5'-di[1-(triethylammonio)methyl]-2,2'-dipyridine

tatpp $=9,11,20,22$-tetraazatetrapyrido[3,2-a:2', $3^{\prime}-\mathrm{c}: 3^{\prime \prime}, 2^{\prime \prime}-1: 2^{\prime \prime \prime}, 3^{\prime \prime \prime}$ n]pentacene

$t \mathrm{Bu}_{2}$ bpy $=4,4^{\prime}$-di-tert -butyl-2,2'-bipyridine

tFPIP = 2-(2-trifluoromethane

f] $[1,10]$ phenanthroline)

tip = 2-(thiophen-2-yl)-1H-imidazo $[4,5-f][1,10]$ phenanthroline $)$

tmphen $=3,4,7,8$,-tetramethyl-1,10-phenantroline

tpphz = tetrapyrido[3,2-a:2',3'-c:3"',2"-h:2'"',3'"'-j]phenazine

ttbpy $=4,4^{\prime}$-ditertiary butyl-2,2'-bipyridine

\section{Cell lines explanation}

4T1 = mouse breast cancer cell line

A2780 = human ovarian carcinoma cell line

$\mathrm{A} 2780-\mathrm{CP} 70=$ cisplatin-resistant ovarian carcinoma cell line

A375 = human melanoma cell line

A549 = human lung adenocarcinoma cell line

$B=B$ lymphocytes cell line

BEL-7402 = human hepatocellular carcinoma cell line

$\mathrm{BHK}=$ baby hamster kidney cell line

$B J A B=$ Burkitt-like lymphoma cell line

CCD-19Lu = human noncancerous normal lung fibroblasts cell line

Du145 = human prostate cancer cell line

EVSA-T = human breast carcinoma cell line

HBL100 = human breast cancer cell line

HCC2998 = human colon adenocarcinoma cell line

HaCaT = aneuploid immortal keratinocyte cell line

HeLa = human adenocarcinoma of the cervix cell line

HEK-293 = human embryonic kidney cell line

HepG-2 = human hepatocarcinoma cell line

HL-60 = human leucocytoma cell line

HOP-62 = human lung adenocarcinoma cell line

$\mathrm{Hs766t}=$ human pancreatic adenocarcinoma cell line

HT-29 = human colon cancer cell line

H226 = human squamous cell lung carcinoma cell line

H358 = human non-small cell lung cancer cell line

IGROV = human ovarian endometrioid adenocarcinoma cell line

LO2 = human hepatic cell lines

$\mathrm{KB}=$ human cervical adenocarcinoma cell line

KB-3-1 = human cervical adenocarcinoma cell line

KB-V-1 = human cervical adenocarcinoma cell line

MCF-7 = human breast carcinoma cell line

MDA-MB-231= human breast adenocarcinoma

MG-63 = human osteosarcoma cell line

MRC-5 = human lung fibroblasts

M19 = human mesothelioma cell line

phenyl)imidazole[4,5- $\quad \mathrm{NIH} / 3 \mathrm{~T} 3=$ Mouse fibroblast

NSCLC $=$ human non-small cell lung cancer cell line

PC12 = rat pheochromocytoma cell line

SGC-7901 = human gastric cancer cell line

$\mathrm{SiHa}=$ human cervical cancer cell line

U2OS = human osteosarcoma cell line

WIDR = human rectosigmoid adenocarcinoma cell line 


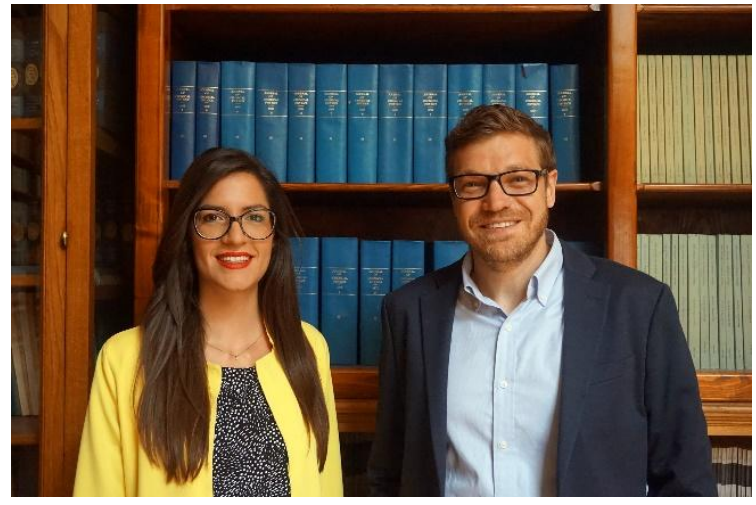

Biographies

\section{Anna Notaro}

Anna Notaro (left) is from a small town near Naples (Italy). She studied at the Università Degli Studi di Napoli "Federico II" were she obtained her master degree in chemical sciences in 2016. During her master thesis, she worked on carbohydrate chemistry under the supervision of Dr. Annalisa Guaragna and Dr. Daniele D’Alonzo. Part of this work was performed at the National University of Ireland (Galway, Ireland) in the frame of an Erasmus for traineeship program under the supervision of Prof. V. Paul Murphy. At the beginning of 2017, Anna started a PhD thesis in the Gasser Group at Chimie ParisTech, PSL Research University (France). She is currently working on the preparation of novel Ru(II) polypyridyl complexes as chemotherapeutic agents.

\section{Gilles Gasser}

Gilles Gasser (right) was born, raised and educated in Switzerland. After a PhD thesis in supramolecular chemistry with Prof. Helen Stoeckli-Evans (University of Neuchâtel, Switzerland), Gilles performed two post-docs, first with the late Prof. Leone Spiccia (Monash University, Australia) in bioinorganic chemisty and then as an Alexander von Humboldt fellow with Prof. Nils Metzler Nolte (Ruhr-University Bochum, Germany) in bioorganometallic chemistry. Gilles then started his independent scientific career at the University of Zurich in 2010 first as a Swiss National Science
Foundation (SNSF) Ambizione Fellow and then as a SNSF Assistant Professor in 2011. In 2016, Gilles moved to Chimie ParisTech, PSL Research University (France), thanks among other to a PSL Chair of Excellence Program Grant. Gilles was the recipient of several fellowships and awards including the Alferd Werner Award from the Swiss Chemical Society, an ERC Consolidator Grant, the Thieme Chemistry Journal Award and recently the Jucker Award for his contribution to cancer research. Gilles's research group aims at utilizing the specific physico-chemical properties of metal complexes in different areas of medicinal chemistry.

\section{Acknowledgements}

We thank Patrick Felder (Chimie ParisTech) for his essential contribution to the graphics. This work was financially supported by an ERC Consolidator Grant PhotoMedMet to G.G. (GA 681679) and has received support under the program Investissements d'Avenir launched by the French Government and implemented by the ANR with the reference ANR-10-IDEX0001-02 PSL (G.G.).

\section{Notes}

The authors declare no competing financial interest.

\section{References}

1 A. Jemal, F. Bray and J. Ferlay, CA. Cancer J. Clin., 2011, 61, 69-90. L. A. Torre, R. L. Siegel, E. M. Ward and A. Jemal, Cancer Epidemiol. Biomarkers Prev., 2015, 25, 16-27. A. Urruticoechea, R. Alemany, J. Balart, A. Villanueva, F. Viñals and G. Capellá, Curr. Pharm. Des., 2010, 16, 3-10. J. Ferlay, H.-R. Shin, F. Bray, D. Forman, C. Mathers and D. M. Parkin, Int. J. Cancer, 2010, 127, 2893-2917.

5 L. A. Torre, F. Bray, R. L. Siegel, J. Ferlay, J. Lortet-tieulent and A. Jemal, CA Cancer J. Clin., 2015, 65, 87-108. C. X. Zhang and S. J. Lippard, Curr. Opin. Chem. Biol., 2003, 7, 481-489. E. Jamieson and S. Lippard, Chem. Rev., 1999, 99, 24672498. E. Wong and C. M. Giandomenico, Chem. Rev., 1999, 99 2451-2466. D. Lebwohl and R. Canetta, Eur. J. Cancer, 1998, 34, 15221534. Med. Chem., 2004, 4, 1525-35.

11 V. Singh, G. K. Azad, A. Reddy M., S. Baranwal and R. S. 
Tomar, Eur. J. Pharmacol., 2014, 736, 77-85. S. P. Fricker, Dalton Trans., 2007, 43, 4903-4917. K. S. M. Smalley, R. Contractor, N. K. Haass, A. N. Kulp, G. E. Atilla-Gokcumen, D. S. Williams, H. Bregman, K. T. Flaherty, M. S. Soengas, E. Meggers and M. Herlyn, Cancer Res., 2007, 67, 209-217.

14 P. G. Corrie, Medicine (Baltimore)., 2007, 36, 24-28.

15 B. Rosenberg, L. Van Camp and T. Krigas, Nature, 1965, 205, 698-699. B. Rosenberg, L. van Camp, E. B. Grimley and A. J. Thomson, J. Biol. Chem., 1967, 242, 1347-52. B. B. Rosenberg, Platin. Met. Rev., 1971, 15, 42-51. B. Rosenberg, L. Van Camp, J. E. Trosko and V. H. Mansour, Nature, 1969, 222, 385-386.

P. Pieter and S. J. Lippard, Encycl. Cancer, 1997, 1, 525543.

J. A. Mello, S. J. Lippard and J. M. Essigmann, Biochemistry, 1995, 34, 14783-91.

M. J. Clarke, F. Zhu and D. R. Frasca, Chem. Rev., 1999, 99, 2511-2533.

M. a Jakupec, M. Galanski, V. B. Arion, C. G. Hartinger and

B. K. Keppler, Dalton Trans., 2008, 183-194.

P. C. Bruijnincx and P. J. Sadler, Curr. Opin. Chem. Biol., 2008, 12, 197-206.

T. Gianferrara, I. Bratsos and E. Alessio, Dalton Trans., 2009, 7588-7598.

G. Gasser, I. Ott and N. Metzler-Nolte, J. Med. Chem., 2011, 54, 3-25.

E. Reisner, V. B. Arion, B. K. Keppler and A. J. L. Pombeiro, Inorg. Chim. Acta, 2008, 361, 1569-1583.

M. J. Clarke, Coord. Chem. Rev., 2003, 236, 209-233.

P. J. Dyson and G. Sava, Dalton Trans., 2006, 1929-33.

D. Chen, V. Milacic, M. Frezza and Q. Dou, Curr. Pharm. Des., 2009, 777-791.

A. C. Komor and J. K. Barton, Chem. Commun., 2013, 49, 3617-3630.

B. C. S. Allardyce and P. J. Dyson, Platin. Met. Rev., 2001, 45, 62-69.

E. S. Antonarakis and A. Emadi, Cancer Chemother.

Pharmacol., 2010, 66, 1-9.

M. Pongratz, P. Schluga, M. A. Jakupec, V. B. Arion, C. G. Hartinger, G. Allmaier and B. K. Keppler, J. Anal. At. Spectrom., 2004, 19, 46-51.

E. Alessio, Eur. J. Inorg. Chem., 2017, 55, 1549-1560.

A. Bergamo and G. Sava, Dalton Trans., 2007, 1267-1272.

G. Sava, I. Capozzi, K. Clerici, G. Gagliardi, E. Alessio and G. Mestroni, Clin. Exp. Metastasis, 1998, 16, 371-379.

F. Lentz, A. Drescher, A. Lindauer, M. Henke, R. a Hilger, C.

G. Hartinger, M. E. Scheulen, C. Dittrich, B. K. Keppler and

U. Jaehde, Anticancer. Drugs, 2009, 20, 97-103.

R. Trondl, P. Heffeter, C. R. Kowol, M. a. Jakupec, W. Berger and B. K. Keppler, Chem. Sci., 2014, 5, 2925-2932.

C. G. Hartinger, S. Zorbas-Seifried, M. A. Jakupec, B. Kynast, H. Zorbas and B. K. Keppler, J. Inorg. Biochem., 2006, 100, 891-904.

V. Brabec, Prog. Nucleic Acid Res. Mol. Biol., 2002, 71, 168.
P. Heffeter, K. Böck, B. Atil, M. A. Reza Hoda, W. Körner, C. Bartel, U. Jungwirth, B. K. Keppler, M. Micksche, W. Berger and G. Koellensperger, J. Biol. Inorg. Chem., 2010, 15, 737748.

42 C. G. Hartinger, M. a Jakupec, S. Zorbas-Seifried, M. Groessl, A. Egger, W. Berger, H. Zorbas, P. J. Dyson and B. K. Keppler, Chem. Biodivers., 2008, 5, 2140-2155. F. Kratz, M. Hartmann, B. K. Keppler and L. Messori, J. Biol. Chem., 1994, 269, 2581-2588.

G. Sava and A. Bergamo, Int. J. Oncol., 2000, 17, 353-365. A. Levina, A. Mitra and P. a Lay, Metallomics, 2009, 1, 458470.

A. Bergamo, C. Gaiddon, J. H. M. Schellens, J. H. Beijnen and G. Sava, J. Inorg. Biochem., 2012, 106, 90-99.

G. Natarajan, R. Malathi and E. Holler, Biochem.

Pharmacol., 1999, 58, 1625-1629.

I. Bratsos, S. Jedner, T. Gianferrara and E. Alessio, Chim. Int. J. Chem., 2007, 61, 692-697.

B.-Z. Zhu, X.-J. Chao, C.-H. Huang and Y. Li, Chem. Sci., 2016, 7, 4016-4023.

M. Dörr and E. Meggers, Curr. Opin. Chem. Biol., 2014, 19, 76-81. 1252.

E. M. P. Mulcahy, Top Organomet Chem, 2010, 32, 141153.

H. Huang, P. Zhang, B. Yu, Y. Chen, J. Wang, L. Ji and H. Chao, J. Med. Chem., 2014, 57, 8971-8983.

H. Huang, P. Zhang, H. Chen, L. Ji and H. Chao, Chemistry, 2015, 21, 715-725.

L. Zeng, Y. Chen, H. Huang, J. Wang, D. Zhao, L. Ji and H. Chao, Chemistry, 2015, 21, 15308-15319.

H. Rico Bautista, R. O. Saavedra Diaz, L. Q. Shen, C. Orvain, C. Gaiddon, R. Le Lagadec and A. D. Ryabov, J. Inorg. Biochem., 2016, 163, 28-38.

L. Zeng, P. Gupta, Y. Chen, E. Wang, L. Ji, H. Chao, Z.-S. Chen, J. Mai, H. Zhang, Z. Li, M. Guevara, Z.-W. Mao, H. Shen, G. Superti-Furga, B. K. Keppler and C. G. Hartinger, Chem. Soc. Rev., , DOI:10.1039/C7CS00195A.

H. A. Wee and P. J. Dyson, Eur. J. Inorg. Chem., 2006, 40034018. D. Chatterjee, A. Mitra and G. S. De, Platin. Met. Rev., 2006, 50, 2-12. V. Brabec and O. Nováková, Drug Resist. Updat., 2006, 9, 111-122.

M. R. Gill and J. A. Thomas, Chem. Soc. Rev., 2012, 41, 3179-3192.

G. Li, L. Sun, L. Ji and H. Chao, Dalton Trans., 2016, 45, 13261-13276.

L. Salassa, Eur. J. Inorg. Chem., 2011, 4931-4947.

F. P. Dwyer, E. C. Gyarfas, W. P. Rogers and J. H. Koch, Nature, 1952, 170, 190-191.

F. P. D. J. H. Koch, C. Gyarfas, 1956, 9, 371-381.

68
J. H Koch, E. C Gyarfas and F. P. Dwyer, Aust. J. Biol. Sci., 1956, 9, 371-381. Rustam I. Aminov, Front. Microbiol., 2010, 1, 1-7. 

Biochemistry, 1992, 31, 10809-10816.

J.-G. Liu, B.-H. Ye, H. Li, Q.-X. Zhen, L.-N. Ji and Y.-H. Fu, J. Inorg. Biochem., 1999, 76, 265-271.

K. E. Erkkila, D. T. Odom and J. K. Barton, Chem. Rev., 1999 99, 2777-2796.

Y. Xiong, X. He, X. Zou, J. Wu, X. Chen, L. Ji, R. Li, J. Zhou and K. Yu, J. Chem. Soc. Dalt. Trans., 1999, 19-23.

L. N. Ji, X. H. Zou and J. G. Liu, Coord. Chem. Rev., 2001, 216-217, 513-536.

A. E. Friedman, J.-C. Chambron, J.-P. Sauvage, N. J. Turro and J. K. Barton, J. Am. Chem. Soc., 1990, 112, 4960-4962. E. J. C. Olson, D. Hu, a Ho, a M. Jonkman, M. R. Arkin, E. D. a Stemp, J. K. Barton and P. F. Barbara, J. Am. Chem. Soc., 1997, 7863, 11458-11467.

C. A. Puckett and J. K. Barton, J. Am. Chem. Soc., 2009, 131 8738-8739.

J. K. Barton, E. D. Olmon and P. A. Sontz, Coord. Chem. Rev., 2011, 255, 619-634.

H. Song, J. T. Kaiser and J. K. Barton, Nat. Chem., 2012, 4, 615-20.

C. R. Cardoso, M. V. S. Lima, J. Cheleski, E. J. Peterson, T. Venâncio, N. P. Farrell and R. M. Carlos, J. Med. Chem., 2014, 57, 4906-4915.

Z.-P. Zeng, Q. Wu, F.-Y. Sun, K.-D. Zheng and W.-J. Mei, Inorg. Chem., 2016, 55, 5710-5718.

M. R. Gill, H. Derrat, C. G. W. Smythe, G. Battaglia and J. A. Thomas, ChemBioChem, 2011, 12, 877-880.

M. Eriksson, M. Leijon, C. Hiort, B. Norden and A.

Graeslund, Biochemistry, 1994, 33, 5031-5040.

G. Yang, J. Z. Wu, L. Wang, L. N. Ji and X. Tian, J. Inorg. Biochem., 1997, 66, 141-144.

J. P. Hall, P. M. Keane, H. Beer, K. Buchner, G. Winter, T. L. Sorensen, D. J. Cardin, J. A. Brazier and C. J. Cardin, Nucleic Acids Res., 2016, 44, 9472-9482.

J. Liu, L. F. Tan, L. H. Jin and F. Luan, DNA Cell Biol., 2012, 31, 250-258.

C. J. Cardin, J. M. Kelly and S. J. Quinn, Chem. Sci., 2017, 8, 4705-4723.

J. K. Barton, A. T. Danishefsky and J. M. Goldberg, J. Am. Chem. Soc., 1984, 106, 2172-2176.

P. Lincoln, A. Broo and B. Norden, J. Am. Chem. Soc., 1996, 2644-2653.

J. Liu, X.-H. Zou, Q.-L. Zhang, W.-J. Mei, J.-Z. Liu and L.-N. Ji, Met. Based Drugs, 2000, 7, 343-348.

A. C. G. Hotze, E. P. L. Van Der Geer, H. Kooijman, A. L. Spek, J. G. Haasnoot and J. Reedijk, Eur. J. Inorg. Chem., 2005, 2, 2648-2657.

D. Ma, C. Che, F. Siu, M. Yang and K. Wong, Inorg. Chem., 2007, 46, 740-749.

P. Zhang, J. Chen and Y. Liang, Acta Biochim. Biophys. Sin., 2010, 42, 440-449.

D. A. Lutterman, A. Chouai, Y. Liu, Y. Sun, C. D. Stewart, K. R. Dunbar and C. Turro, J. Am. Chem. Soc., 2008, 130, 1163-1170.

J. F. Kou, C. Qian, J. Q. Wang, X. Chen, L. L. Wang, H. Chao and L. N. Ji, J. Biol. Inorg. Chem., 2012, 17, 81-96.
K. J. Du, J. Q. Wang, J. F. Kou, G. Y. Li, L. L. Wang, H. Chao and L. N. Ji, Eur. J. Med. Chem., 2011, 46, 1056-1065. Y. C. Wang, C. Qian, Z. L. Peng, X. J. Hou, L. L. Wang, H. Chao and L. N. Ji, J. Inorg. Biochem., 2014, 130, 15-27. C. Wang, Q. Yu, L. Yang, Y. Liu, D. Sun, Y. Huang, Y. Zhou, Q. Zhang and J. Liu, BioMetals, 2013, 26, 387-402.

Z. Zhang, Q. Wu, X. H. Wu, F. Y. Sun, L. M. Chen, J. C. Chen, S. L. Yang and W. J. Mei, Eur. J. Med. Chem., 2014, 80, 316324.

P. Venkat Reddy, M. Rajender Reddy, S. Avudoddi, Y. Praveen Kumar, C. Nagamani, N. Deepika, K. Nagasuryaprasad, S. Satyanarayana Singh and S. Satyanarayana, Anal. Biochem., 2015, 485, 49-58. N. Deepika, C. Shobha Devi, Y. Praveen Kumar, K. Laxma Reddy, P. Venkat Reddy, D. Anil Kumar, S. S. Singh and S. Satyanarayana, J. Photochem. Photobiol. B Biol., 2016, 160, 142-153.

J. C. Wang, Annu. Rev. Biochem., 1996, 65, 635-692. J. J. Champoux, Annu. Rev. Biochem., 2001, 70, 369-413.

J. C. Wang, Nat. Rev. Mol. Cell. Biol., 2002, 3, 430-440.

T. Simonsson, Biol. Chem., 2001, 382, 621-628.

L. H. Hurley, Biochem. Soc. Trans., 2001, 29, 692-696.

C. Metcalfe and J. a Thomas, Chem. Soc. Rev., 2003, 32, 215-224.

X. Chen, J.-H. Wu, Y.-W. Lai, R. Zhao, H. Chao and L.-N. Ji, Dalton Trans., 2013, 42, 4386-4397.

Q. Yu, Y. Liu, C. Wang, D. Sun, X. Yang, Y. Liu and J. Liu, PLoS One, 2012, 7, 1-13.

S. Shi, J. Xu, X. Gao, H. Huang and T. Yao, Chem. - A Eur. J., 2015, 21, 11435-11445.

A. Srishailam, Y. P. Kumar, P. Venkat Reddy, N. Nambigari, U. Vuruputuri, S. S. Singh and S. Satyanarayana, J. Photochem. Photobiol. B Biol., 2014, 132, 111-123. U. Schatzschneider, J. Niesel, I. Ott, R. Gust, H. Alborzinia and S. Wölfl, ChemMedChem, 2008, 3, 1104-1109.

S. Schäfer, I. Ott, R. Gust and W. S. Sheldrick, Eur. J. Inorg. Chem., 2007, 3034-3046.

F. Gao, X. Chen, J. Q. Wang, Y. Chen, H. Chao and L. N. Ji, Inorg. Chem., 2009, 48, 5599-5601.

. Zava, S. M. Zakeeruddin, C. Danelon, H. Vogel, M. Grätzel and P. J. Dyson, ChemBioChem, 2009, 10, 17961800.

T. Chen, Y. Liu, W. J. Zheng, J. Liu and Y. S. Wong, Inorg. Chem., 2010, 49, 6366-6368.

C. Tan, S. Lai, S. Wu, S. Hu, L. Zhou, Y. Chen, M. Wang, Y. Zhu, W. Lian, W. Peng, L. Ji and A. Xu, J. Med. Chem., 2010, 53, 7613-7624.

S. P. Mulcahy, K. Gründler, C. Frias, L. Wagner, A. Prokop and E. Meggers, Dalton Trans., 2010, 39, 8177-82.

T. Chen, W.-J. Mei, Y.-S. Wong, J. Liu, Y. Liu, H.-S. Xie and W.-J. Zheng, Med. Chem. Comm., 2010, 1, 73-75.

C. Tan, S. Wu, S. Lai, M. Wang, Y. Chen, L. Zhou, Y. Zhu, W. Lian, W. Peng, L. Ji and A. Xu, Dalton Trans., 2011, 40, 8611-8621.

K. M. Debatin, Toxicol. Lett., 2000, 112-113, 41-48.

U. K. Mazumder, M. Gupta, S. S. Karki, S. Bhattacharya, S. Rathinasamy and S. Thangavel, Chem. Pharm. Bull. 
(Tokyo)., 2004, 52, 178-185.

L. C. Tu, C. S. Chen, I. C. Hsiao, J. W. Chern, C. H. Lin, Y. C. Shen and S. F. Yeh, Chem. Biol., 2005, 12, 1317-1324.

124 V. Pierroz, T. Joshi, A. Leonidova, C. Mari, J. Schur, I. Ott, L. Spiccia, S. Ferrari and G. Gasser, J. Am. Chem. Soc., 2012, 134, 20376-20387.

125 G.-B. Jiang, Y.-Y. Xie, G.-J. Lin, H.-L. Huang, Z.-H. Liang and Y.-J. Liu, J. Photochem. Photobiol. B., 2013, 129, 48-56.

126 C. Qian, J.-Q. Wang, C.-L. Song, L.-L. Wang, L.-N. Ji and H. Chao, Metallomics, 2013, 5, 844-854.

127 Y. Yuan, A. Y. Wang, A. L. Jiang, A. F. Gao, A. S. Liang, C. Su, A. H. Chao and L. J. A, Aust. J. Chem., 2008, 61, 732-739.

128 Y. Y. Xie, Z. Z. Li, G. J. Lin, H. L. Huang, X. Z. Wang, Z. H. Liang, G. Bin Jiang and Y. J. Liu, Inorganica Chim. Acta, 2013, 405, 228-234.

129 G. J. Lin, Z. Z. Li, J. H. Yao, H. L. Huang, Y. Y. Xie and Y. J. Liu, Aust. J. Chem., 2013, 66, 555-563.

130 B.-J. Han, G.-B. Jiang, J. Wang, W. Li, H.-L. Huang and Y.-J. Liu, RSC Adv., 2014, 4, 40899-40906.

131 W. Li, G.-B. Jiang, J.-H. Yao, X.-Z. Wang, J. Wang, B.-J. Han, Y.-Y. Xie, G.-J. Lin, H.-L. Huang and Y.-J. Liu, J. Photochem. Photobiol. B., 2014, 140, 94-104.

132 Y. Du, X. Fu, H. Li, B. Chen, Y. Guo, G. Su, H. Zhang, F. Ning, Y. Lin, W. Mei and T. Chen, ChemMedChem, 2014, 9, 714718.

133 G. Bin Jiang, X. Zheng, J. H. Yao, B. J. Han, W. Li, J. Wang, H. L. Huang and Y. J. Liu, J. Inorg. Biochem., 2014, 141, 170179.

134 G.-B. Jiang, J.-H. Yao, J. Wang, W. Li, B.-J. Han, Y.-Y. Xie, G.J. Lin, H.-L. Huang and Y.-J. Liu, New J. Chem., 2014, 38, 2554-2563.

135 Q. Yu, Y. Liu, L. Xu, C. Zheng, F. Le, X. Qin, Y. Liu and J. Liu, Eur. J. Med. Chem., 2014, 82, 82-95.

136 O. Mazuryk, M. Maciuszek, G. Stochel, F. Suzenet and M. Brindell, J. Inorg. Biochem., 2014, 134, 83-91.

137 O. Mazuryk, F. Suzenet, C. Kieda and M. Brindell, Metallomics, 2015, 7, 553-566.

138 S. Kizaka-Kondoh and H. Konse-Nagasawa, Cancer Sci., 2009, 100, 1366-1373.

C. Kieda, B. El Hafny-Rahbi, G. Collet, N. Lamerant-Fayel, C. Grillon, A. Guichard, J. Dulak, A. Jozkowicz, J. Kotlinowski,

K. C. Fylaktakidou, A. Vidal, P. Auzeloux, E. Miot-Noirault, J. C. Beloeil, J. M. Lehn and C. Nicolau, J. Mol. Med., 2013, 91, 883-899.

140 S. H. Lai, G. Bin Jiang, J. H. Yao, W. Li, B. J. Han, C. Zhang, C. C. Zeng and Y. J. Liu, J. Inorg. Biochem., 2015, 152, 1-9.

141 C. Zhang, B.-J. Han, C.-C. Zeng, S.-H. Lai, W. Li, B. Tang, D. Wan, G.-B. Jiang and Y.-J. Liu, J. Inorg. Biochem., 2016, 157, 62-72.

142 S. Liu, J. Zhu, H. Xu, Y. Wang, Y. Liu, J. Liang, G. Zhang, D. Cao, Y. Lin, Y. Wu and Q. Guo, Spectrochim. Acta Part A Mol. Biomol. Spectrosc., 2016, 161, 77-82.

143 C.-C. Zeng, S.-H. Lai, J.-H. Yao, C. Zhang, H. Yin, W. Li, B.-J. Han and Y.-J. Liu, Eur. J. Med. Chem., 2016, 122, 118-126. D. Wan, S.-H. Lai, H.-H. Yang, B. Tang, C. Zhang, H. Yin, C.-C.
Zeng and Y.-J. Liu, J. Photochem. Photobiol. B Biol., 2016, 161, 295-303.

D. Wan, S.-H. Lai, H.-H. Yang, B. Tang, C. Zhang, H. Yin, C.-C. Zeng and Y.-J. Liu, J. Photochem. Photobiol. B Biol., 2016, 165, 246-255.

D. Wan, S.-H. Lai, C.-C. Zeng, C. Zhang, B. Tang and Y.-J. Liu, J. Inorg. Biochem., 2017, 173, 1-11.

Z. Luo, L. Yu, F. Yang, Z. Zhao, B. Yu, H. Lai, K.-H. Wong, S.M. Ngai, W. Zheng and T. Chen, Metallomics, 2014, 6, 1480-1490.

I. Ott, X. Qian, Y. Xu, D. H. W. Vlecken, I. J. Marques, D. Kubutat, J. Will, W. S. Sheldrick, P. Jesse, A. Prokop and C. P. Bagowski, J. Med. Chem., 2009, 52, 763-770. M. Yamada, A. Tomida, H. Yoshikawa, Y. Taketani and T. Tsuruo, Clin. Cancer Res., 1996, 2, 427-432.

S. Prast-Nielsen, M. Cebula, I. Pader and E. S. J. Arnér, Free Radic. Biol. Med., 2010, 49, 1765-1778.

A. Casini, C. Gabbiani, F. Sorrentino, M. P. Rigobello, A. Bindoli, T. J. Geldbach, A. Marrone, N. Re, C. G. Hartinger, P. J. Dyson and L. Messori, J. Med. Chem., 2008, 51, 67736781.

L. Oehninger, M. Stefanopoulou, H. Alborzinia, J. Schur, S Ludewig, K. Namikawa, A. Muñoz-Castro, R. W. Köster, K. Baumann, S. Wölfl, W. S. Sheldrick and I. Ott, Dalton Trans., 2013, 42, 1657-66.

A. Meyer, C. P. Bagowski, M. Kokoschka, M. Stefanopoulou, H. Alborzinia, S. Can, D. H. Vlecken, W. S. Sheldrick, S. Wölfl and I. Ott, Angew. Chemie Int. Ed., 2012, 51, 8895-8899. G. I. Pascu, A. C. G. Hotze, C. Sanchez-Cano, B. M. Kariuki and M. J. Hannon, Angew. Chemie Int. Ed., 2007, 46, 43744378.

U. Mcdonnell, J. M. C. A. Kerchoffs, R. P. M. Castineiras, M. R. Hicks, A. C. G. Hotze, J. Hannon and A. Rodger, Dalton Trans., 2008, 667-675.

T. K. Janaratne, A. Yadav, F. Ongeri and F. M. MacDonnell, Inorg. Chem., 2007, 46, 3420-3422.

T. Yamaguchi, H. Nomura, K. Matsunaga, S. Ito, J. Takata and Y. Karube, Biol. Pharm. Bull., 2003, 26, 1523-1527.

T. Yamaguchi, S. Matsumoto and K. Watanabe, Tetrahedron Lett., 1998, 39, 8311-8312.

G. L. Semenza, J. Mol. Med., 2007, 85, 1301-1307.

A. Yadav, T. Janaratne, A. Krishnan, S. S. Singhal, S. Yadav, A. S. Dayoub, D. L. Hawkins, S. Awasthi and F. M.

Macdonnell, Mol. Cancer Ther., 2013, 12, 643-653. M. R. Gill, J. Garcia-Lara, S. J. Foster, C. Smythe, G. Battaglia and J. a Thomas, Nat. Chem., 2009, 1, 662-667.

C. A. Puckett and J. K. Barton, J. Am. Chem. Soc., 2007, 129, 46-47.

C. A. Puckett and J. K. Barton, Biochemistry, 2008, 47, 11711-11716.

N. Alatrash, E. S. Narh, A. Yadav, M.-J. Kim, T. Janaratne, J. Gabriel and F. M. MacDonnell, ChemMedChem, 2017, 12, 1055-1069.

C. A. Griffith, A. Dayoub, T. Janaratne, N. Alatrash, K. Abayan, A. Mohamedi, Z. Breitbach, D. W. Armstrong and F. M. MacDonnell, Chem. Sci., 2017, 8, 3726-3740. R. Franco, M. I. Panayiotidis and J. A. Cidlowski, J. Biol. 
Chem., 2007, 282, 30452-30465.

167 A. R. Giandomenico, G. E. Cerniglia, J. E. Biaglow, C. W. Stevens and C. J. Koch, Free Radic. Biol. Med., 1997, 23, 426-434.

168 M. J. Pisani, D. K. Weber, K. Heimann, J. G. Collins and F. R. Keene, Metallomics, 2010, 2, 357-432.

169 M. J. Pisani, P. D. Fromm, Y. Mulyana, R. J. Clarke, H. Körner, K. Heimann, J. G. Collins and F. R. Keene, ChemMedChem, 2011, 6, 848-858.

170 Y. Mulyana, D. K. Weber, D. P. Buck, C. A. Motti, J. G. Collins and F. R. Keene, Dalton Trans., 2011, 40, 1510

171 F. Li, Y. Mulyana, M. Feterl, J. M. Warner, J. G. Collins and F. R. Keene, Dalton Trans., 2011, 40, 5032.

172 X. Li, A. K. Gorle, T. D. Ainsworth, K. Heimann, C. E. Woodward, J. Grant Collins and F. Richard Keene, Dalt. Trans., 2014, 44, 3594-3603.

173 M. R. Gill, D. Cecchin, M. G. Walker, R. S. Mulla, G. Battaglia, C. Smythe and J. a Thomas, Chem. Sci., 2013, 4, 4512-4519.

174 J. Lippincott-Schwartz and R. D. Phair, Annu. Rev. Biophys., 2010, 39, 559-578. 